\title{
Innovative concepts and technologies in the restoration of St Martin church at Meise (B)
}

Dionys Van Gemert, Triconsult nv, Lummen, en KU Leuven

Gert Heirman, Triconsult nv, Lummen, en UAntwerpen

Dirk Geeroms, Architect, Gent

\begin{abstract}
The restoration of St Martin church started end of the 1990's by lacing-up the building with stabilizing steel frames. The layout of the lacing-up frames was inspired by the assumption that the observed cracks and deformations in the building were caused by differential settlements of the foundations. Further investigations during the final restoration works in 2011-2012 revealed that cracks were caused by inappropriate foundation interventions as part of an earlier restoration project in 1949-1950 as well as by non-balanced forces from the vaults. Based on the new findings the global restoration concept was adapted and strongly simplified.
\end{abstract}

Keywords: historical masonry, restoration, consolidation injection, structural analysis, vault forces, strengthening

\section{Introduction}

The late-Gothic style St Martin church at Meise was built in the 16th and first half of the 17th Centuries. It is located in the centre of the village on a hill slope, with a walled cemetery, Fig. 1 .

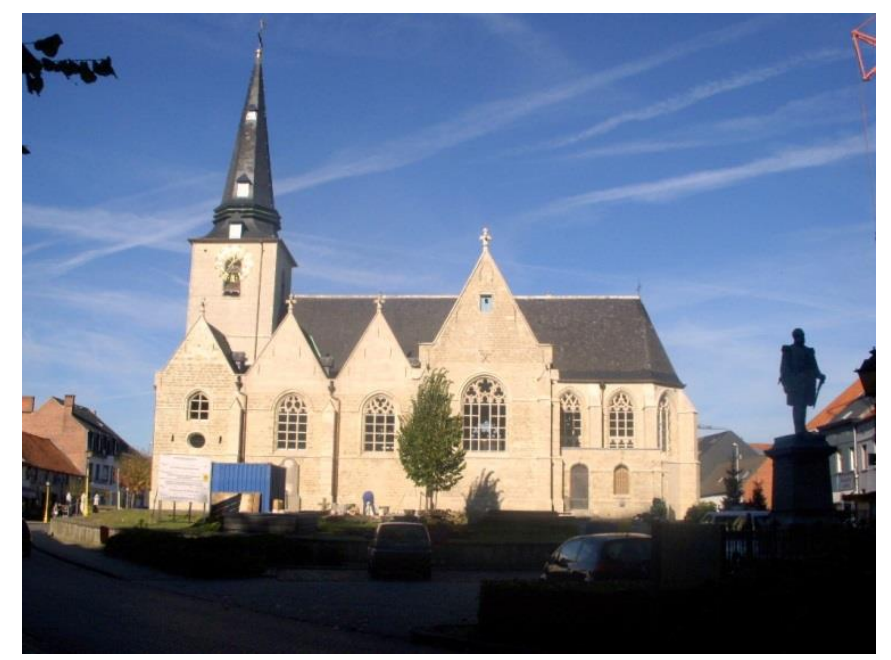

Fig. 1 Saint Martin church in the village centre of Meise (photograph 31 October 2012)

The church has a symmetrical ground plan: built in west tower with baptistery chapel at north of the tower, and store chapel with circular stair tower as entrance to the tower upper stories south of the tower; a three aisled nave with two bays (first half $17^{\text {th }}$ Century), and slightly jutting out transept (first half $16^{\text {th }}$ Century. More recent sacristies north and south of the choir. [1] The ground plan of the church is shown in Fig. 2. 


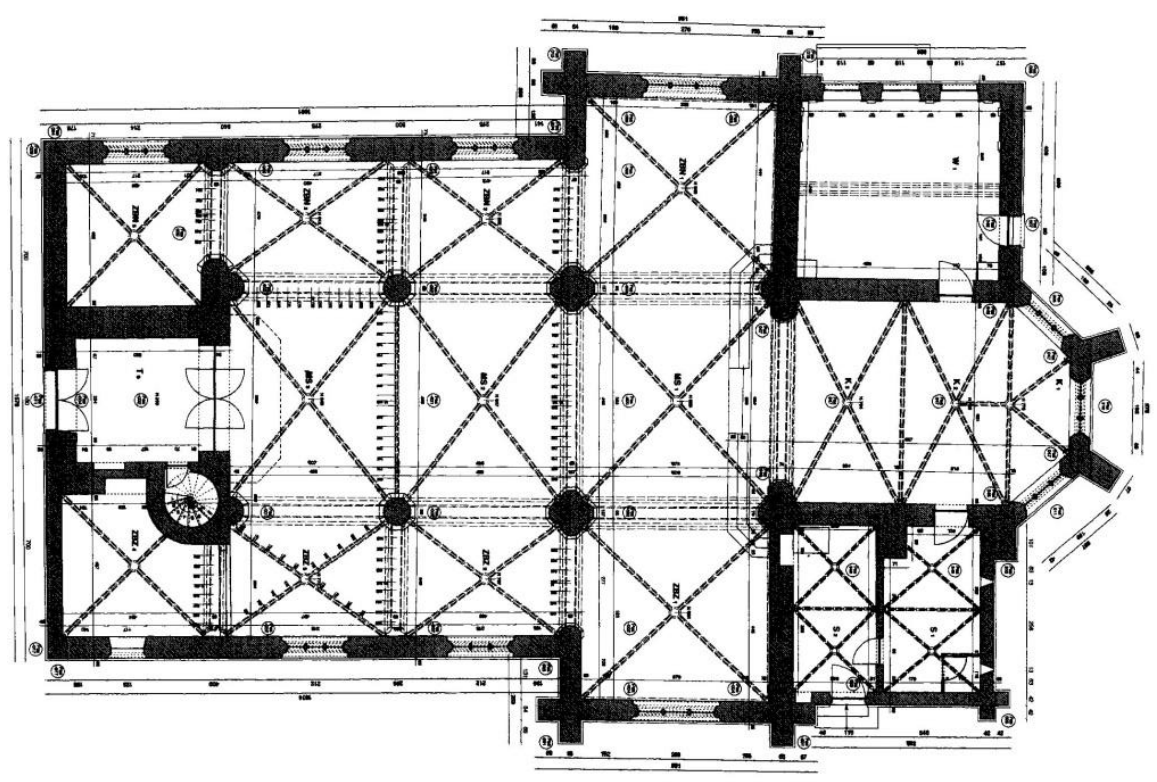

Fig. 2 Ground plan of St Martin church at Meise

At the end of the 1990's alarming cracks were observed in the vaults and arches, as well as opening of the building seems between the tower and the adjacent chapels, Figures 3 and 9 .

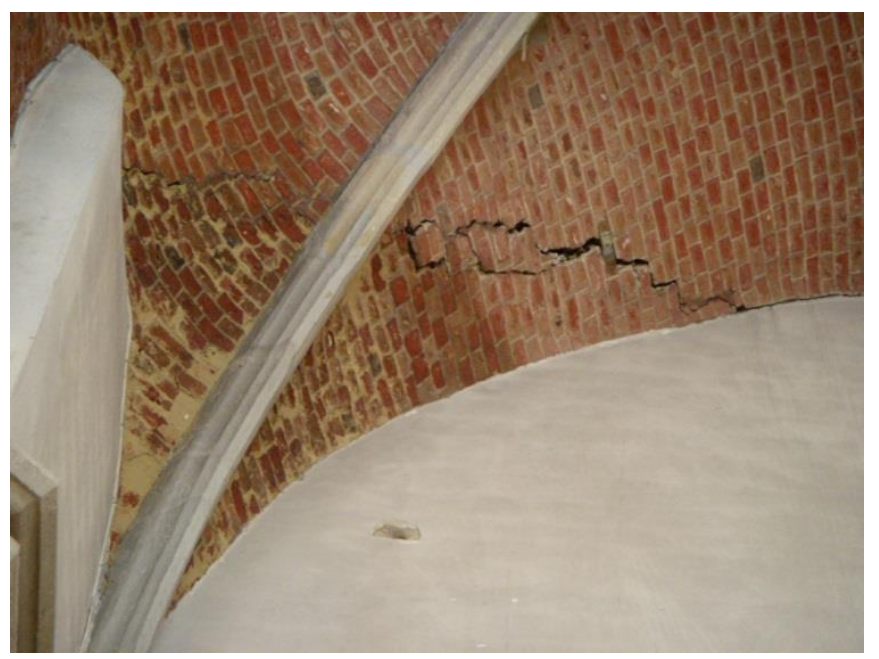

Fig. 3 Cracked vault in SW corner of baptistery chapel (2011)

A heavy steel lacing-up construction was placed in and around the building, to prevent the walls from further tilting, Figures 4 and 5, as it was assumed that differential settlements of the foundations caused the deformations and cracks. These stabilizing frames allowed the further use of the church until the start of the restoration works in April 2011. 


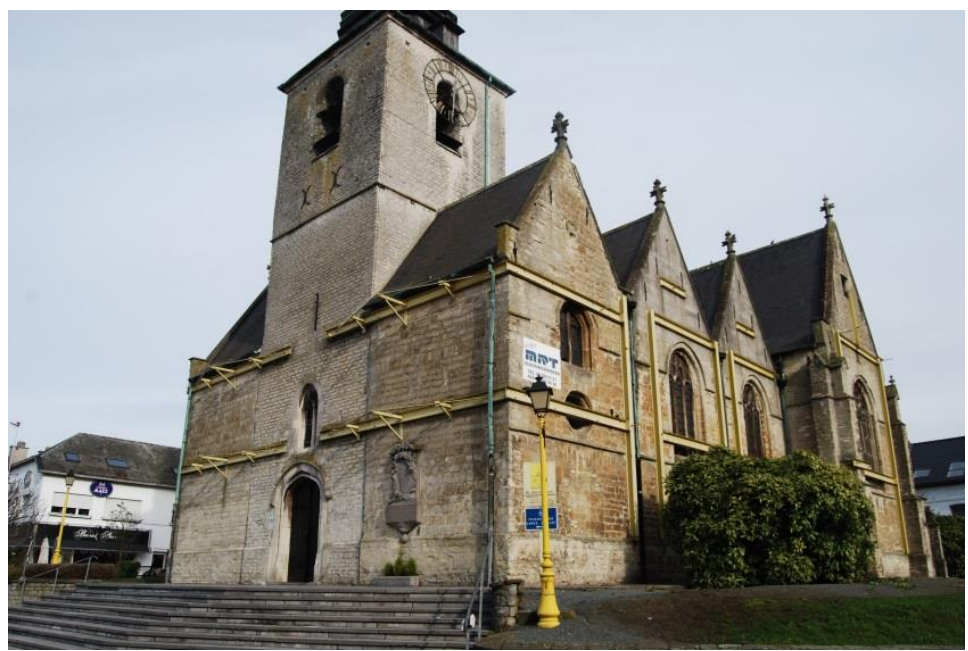

Fig. 4 Stabilizing steel frames for west and south façades (Photograph D. Snauwaert)

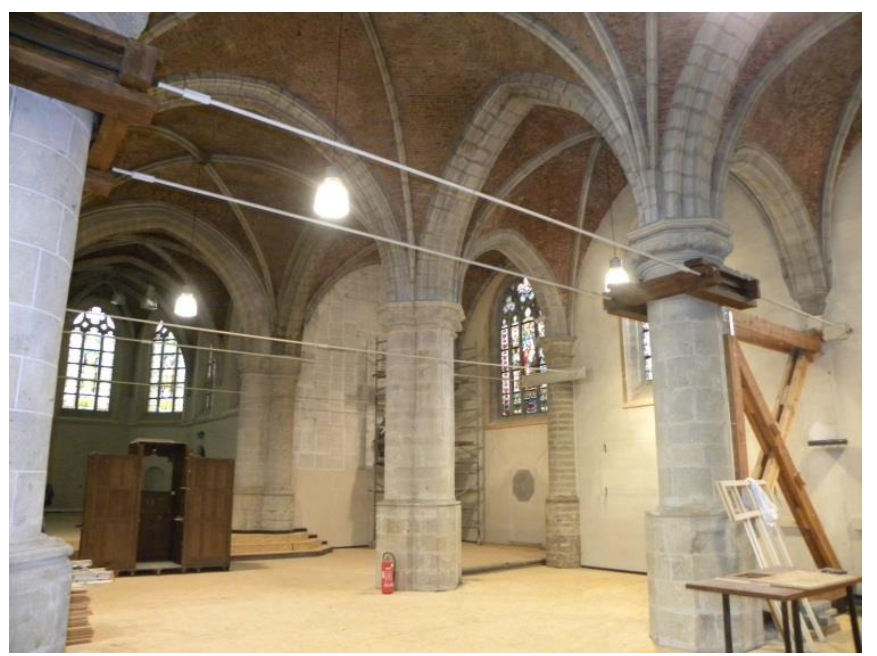

Fig. 5 Double anchors between north and south walls, combined with compression stiff cross shores in the side aisles, and tension stiff connection to the column heads secure the northsouth stiffness of the church nave.

It may be clear that such constructions in the church interior were very annoying for the service and for the perception of the space. To counteract the assumed settlements, the original stabilizing concept would put the north and south wall of the nave as well as the north and south chapel at the tower on new foundation footings supported by micropiles. A system of permanent north-south anchors would be placed, which had to be anchored in additional buttresses at the north, west and south façade. A total of eight additional buttresses was planned.

However, archaeological excavations preceding the planned foundation works revealed the existence of a concrete footing under the total length of the south wall of the nave. The footing had a width of about $3 \mathrm{~m}$. Further research in the Church archives learned that already in 1938 a visual investigation was made by the architect Victor Degand, who proposed to place that footing [2]. He proposed a footing with a length of $17 \mathrm{~m}$, width of $4 \mathrm{~m}$ and thickness of $0.50 \mathrm{~m}$. Execution had to done in about 15 consecutive pieces. He also observed that the lower part of the foundations consisted of natural stone masonry without mortar. Therefor he prescribed to remove the earth filling of the masonry joints as deep as possible at the outside as well as at the inside, and to fill the emptied joints with cement mortar. However, how that had to be done, was not described. It will be demonstrated hereafter that 
inappropriate execution of this refilling of joints has been one of the main reasons for the observed cracks and deformations. Because of Second World War circumstances the project design was delayed to 1948 [3], and the restoration project was executed in 1949-1950.

\section{Crack pattern and preliminary stabilizing measures}

The report of architect Degand mentioned that the four freestanding columns (see Fig. 2) all showed a small inclination to the south: $6 \mathrm{~mm}$ over a height of $1.24 \mathrm{~m}$. The south façade of the transept had an inclination of $113 \mathrm{~mm}$ over a height of $6 \mathrm{~m}$ measured from ground level. Important cracks in the south-west wall of the transept as well as in the wall part of this wall above the main arch of the south side-aisle corresponded to those deformations. These cracks have been repaired in the 1949-1950 restoration campaign.

Deformations were also observed at the storage chapel at the south side of the tower. Architect Degand mentioned cracks at the locking stone of the main arch between chapel and first bay of the south side-aisle, as well as cracks in the vaults, Fig. 3. However, no information could be found about an eventual repair of these cracks in the 1949-1950 campaign. Architect Degand also mentioned that the supporting timber beam of the balustrade of the rood loft in the south chapel moved out of the masonry wall over several $\mathrm{cm}$, Fig. 6, 7. All secondary beams of the wooden floor showed an analogous shift. The south wall of the chapel inclined to the south by $80 \mathrm{~mm}$ over a height of $6 \mathrm{~m}$, corresponding with the top of the chapel vault. The south wall of the adjacent bay of the south side-aisle inclined by $55 \mathrm{~mm}$ over a height of $6.45 \mathrm{~m}$. These inclinations caused the sliding out of the floor beams. These sliding out movements could still be observed at the start of the restoration works in 2011, as well as the solution to this problem provided in the 1949-1950 restoration campaign: extension of the support of the beams by means of a supporting purlin attached to the wall, Fig. 8.

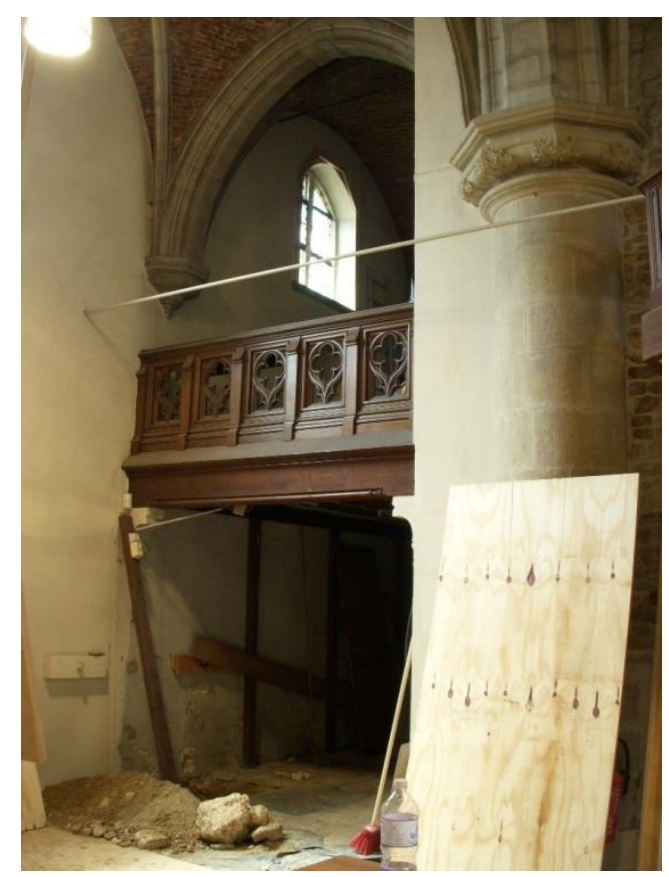

Fig. 6 Balustrade of rood loft in south chapel at tower 


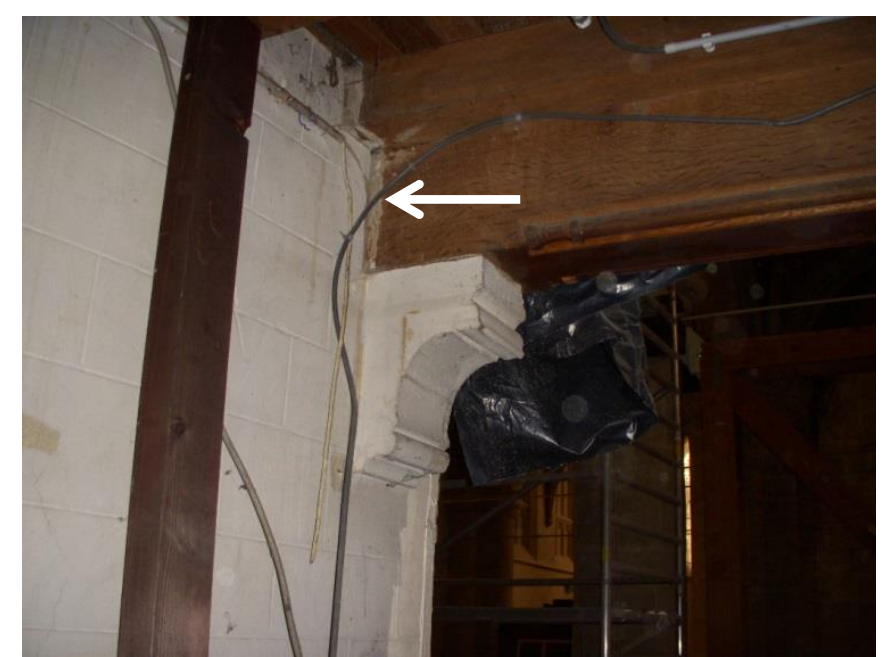

Fig. 7 Supporting timber beam slid out of wall (arrow) (2011)

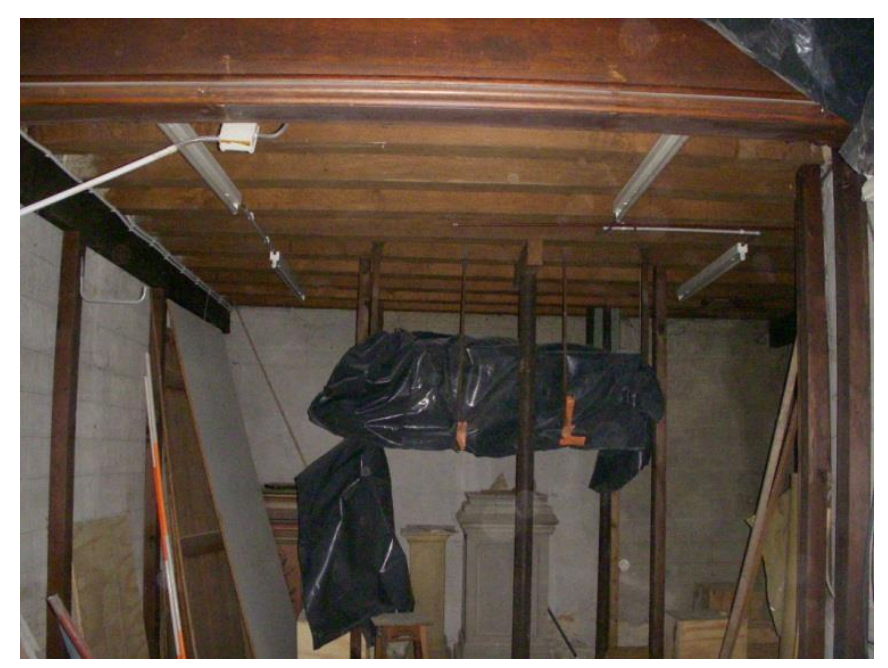

Fig. 8 Left: supporting purlin at straight wall part, serving as extended support for secondary floor beams. Middle: separate steel struts to support the bellows of the organ. (2011)

All these cracks and slides could still be observed in 2011, with the same ordre of magnitude as reported by architect Degand in 1939, as well as the additional floor support constructions of 1949-1950. Therefrom, the new restoration concept assumed that the cracks in the main arch above the rood loft had not been repaired in 1949-1950. Moreover, it could be concluded that only very limited additional deformations after 1950 might have happened. The teared off vault tips at the connection of the north chapel with the tower had already been reported in 1939, Fig. 3. The open construction joints in the west façade between the tower and the chapels were also already reported by architect Degand, Fig. 9. A crack opening of $20 \mathrm{~mm}$ was reported for the south chapel. For the north chapel, it was only mentioned that the crack opening was less. 


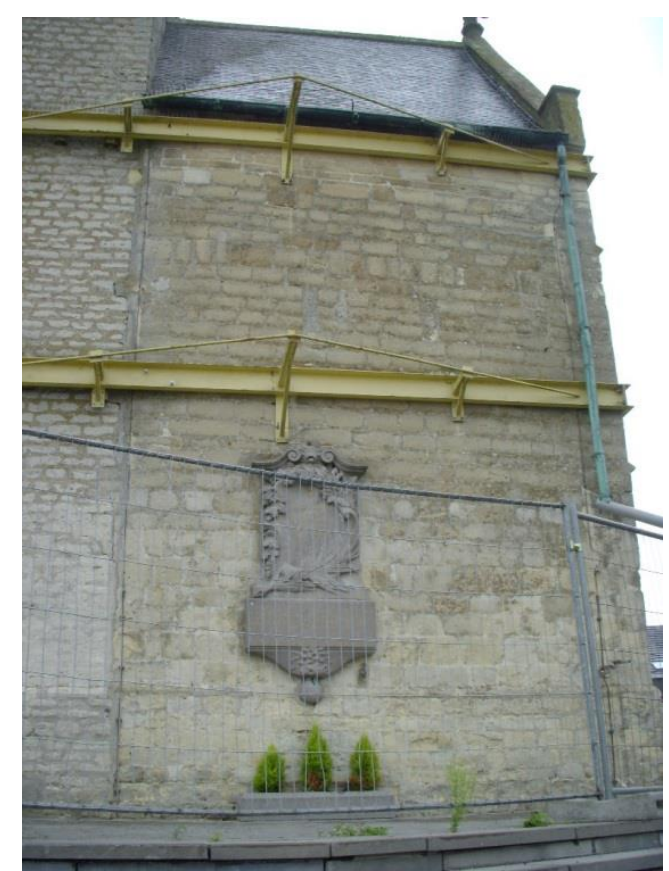

Fig. 9 Open construction joint in west façade between south chapel and tower (2011)

Our investigations in 2011 revealed that the west wall of the chapels also showed a lateral displacement to the west. The observed crack patterns and incline of walls indicate that the building suffered from foundation differential settlements. But some of the deformations and inclines had already been integrated and stabilized in a successive construction or renovation phase, e.g. the incline of the south-east crossing column, Fig. 10. The incline of this column is about $2 \mathrm{~cm}$ per $\mathrm{m}$ height. However, the transept wall perfectly fits to the column, without any fissure in the wall plane. That is only possible when the wall is built afterwards against the column. The same holds for the north-east column.

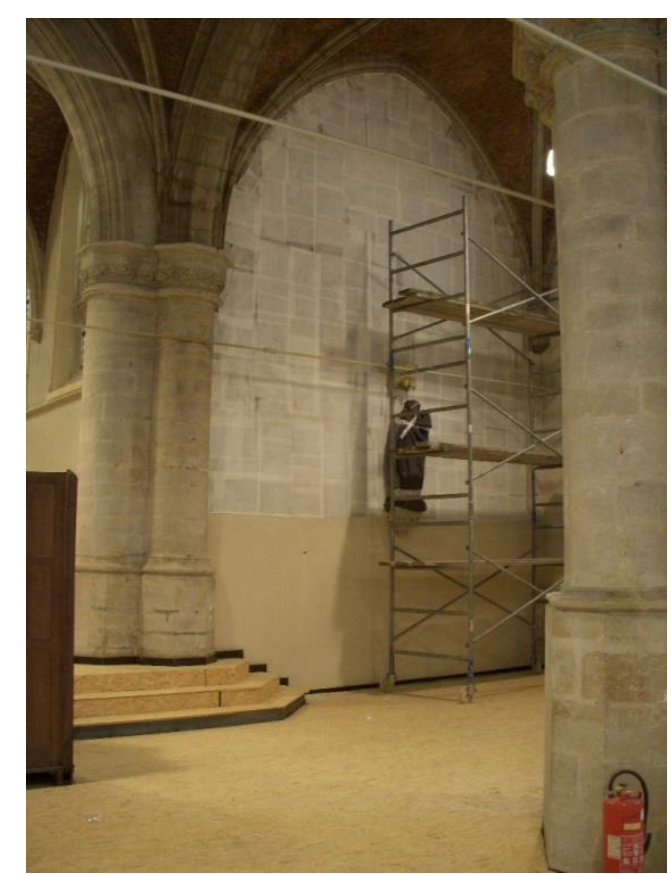

Fig. 10 South-east crossing column, corner between choir and transept, with strong incline. Wall painting covered with Japanese paper, for protection during restoration works. 
Based on the observed global inclination in the south direction and on the crack patterns caused by it, a preliminary steel lacing-up construction was designed to enhance the stiffness of the church building in the north-south direction, and applied in the late 1990's. Anchors crossing the entire width of the church were installed on two levels (one level at the column heads, the other in the attics above the vaults), Figures 5 and 11.

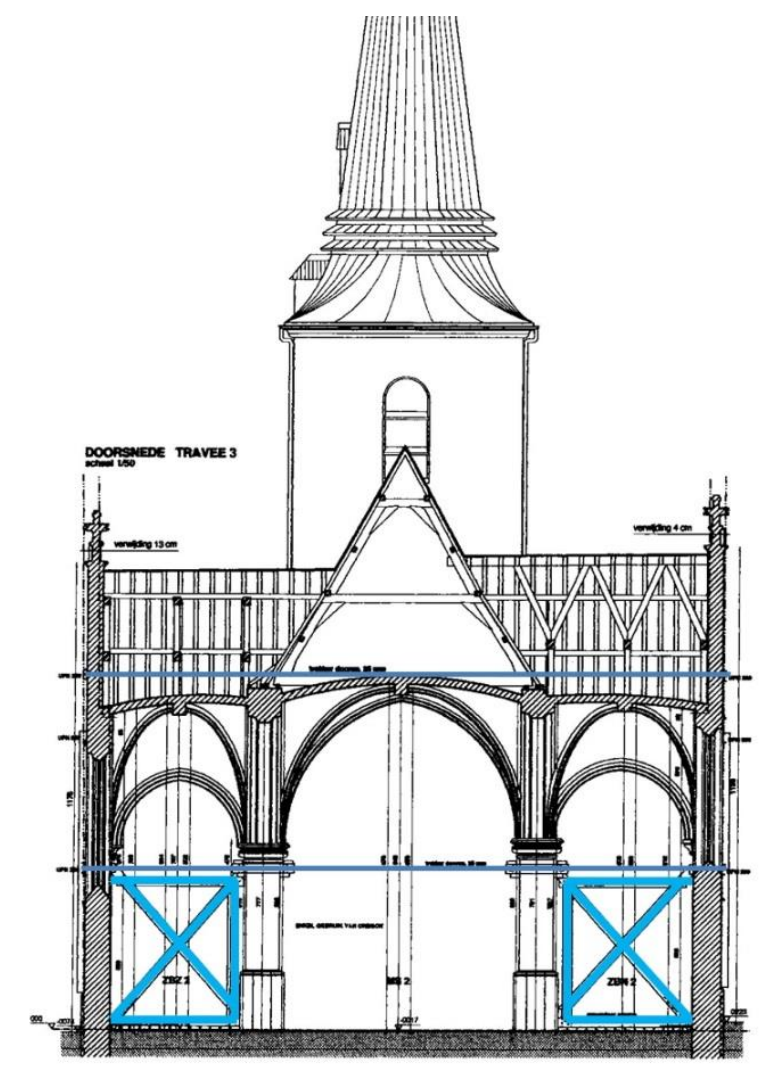

Fig. 11 Tension rods for the free standing columns: one at level of column heads; one above the vaults

The tension rods are connected to the exterior stabilizing frames, Fig. 4. The bottom layer of anchors at the level of the column heads is shown Fig. 5. The free standing columns are enclosed by means of two tension rods. These two rods are fixed to a wooden collar at the column head, ensuring that the same anchors can also be used to balance the horizontal forces coming from the vaults. At the level of the free standing columns a timber Andreas cross is placed in the side-aisles to block the north-south movement of walls and columns. The collar and the Andreas cross constructions are shown in Fig. 12. 


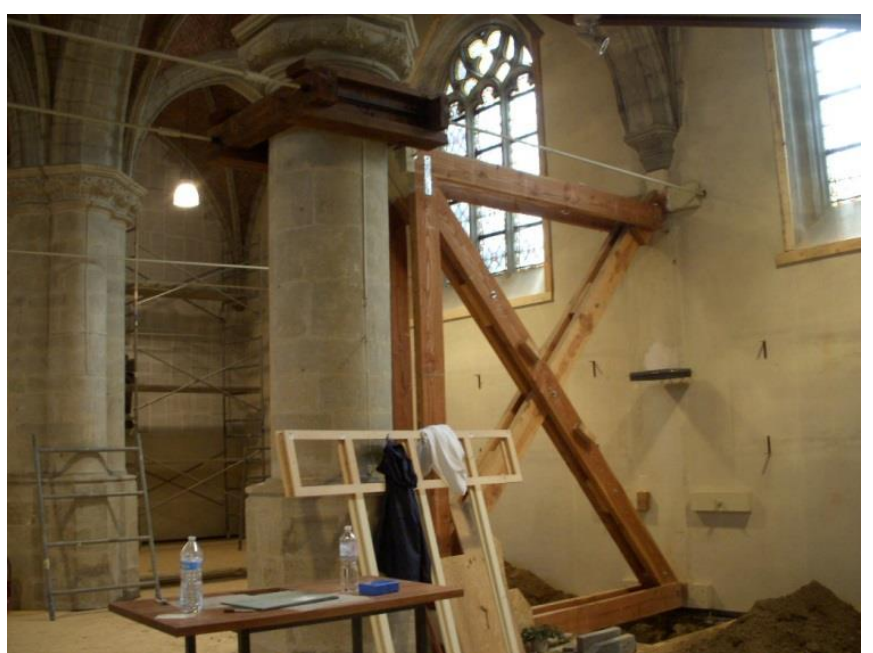

Fig. 12 Collar and Andreas cross in side-aisle

The anchors above the vaults are shown in Fig. 13. The yellow steel beams replace the deteriorated timber ties of the roof trusses.

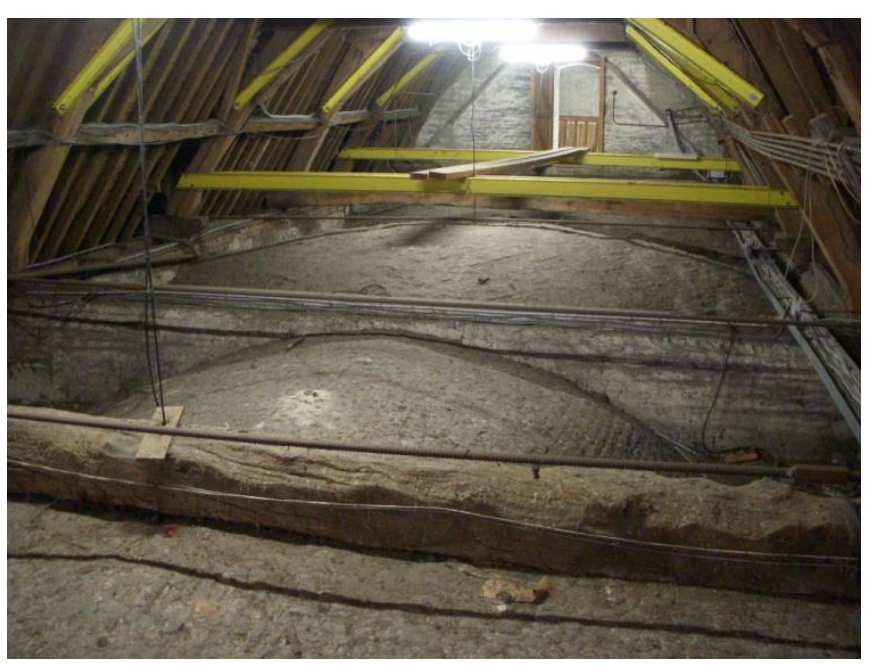

Fig. 13 Anchors above nave vaults

In this way the church building is strengthened and stiffened in the north-south direction with a steel framework, with three bays and two levels. The gables at the north and south side are connected to the frames. Additionally, the north and south chapel at the tower are stabilized with a special triangular frame, Fig. 9. Here too the strengthening frames are placed at two levels. The horizontal steel beams pass the building joint with the tower, in which the beams are anchored. In the corner the beams on the west wall are bolted to the perpendicular beams. In this way the westward movement as well as the northward movement for the north chapel and the southward movement for the south chapel are stopped.

\section{Evaluation of the structural problems}

\subsection{Specific problematic of wall paintings on transept walls}

The original restoration concept considered large and continuing differential foundation settlements as the cause of increasing inclines and increasing cracking. To stop the settlement process, it was considered to add extra buttresses at the north and south walls at the level of 
the freestanding columns and of the crossing columns, as well as two extra buttresses in the north-west corner (one directed to the north and one directed to the west) to block the settlement of the north chapel, and two buttresses in the south-west corner (directed south and west) to block the south chapel movements. The extra buttresses as well as the chapel foundations and the foundations of the side walls would be supported by means of micropiles.

The settlements of the transept ails had caused a large crack in the dividing wall between nave and choir, Fig. 14.

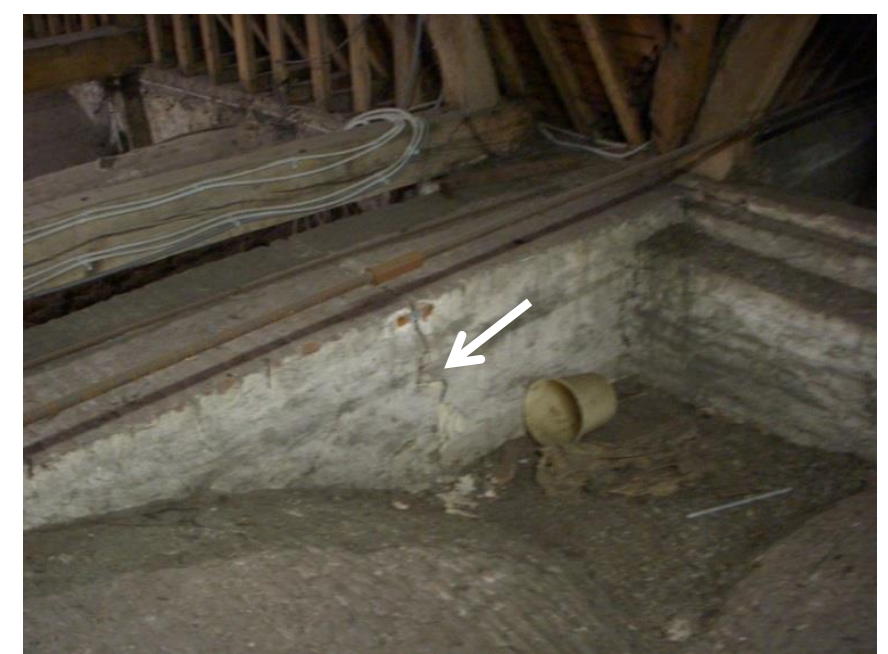

Fig. 14 Crack in dividing wall between transept and choir. Crack opening about $25 \mathrm{~mm}$.

Originally the plan was to drill an anchor through this dividing wall from north to south, to connect the north and south parts of the wall and to stop the movement in the crack. Important wall paintings are present on the north and south parts of the dividing walls, Fig. 15.

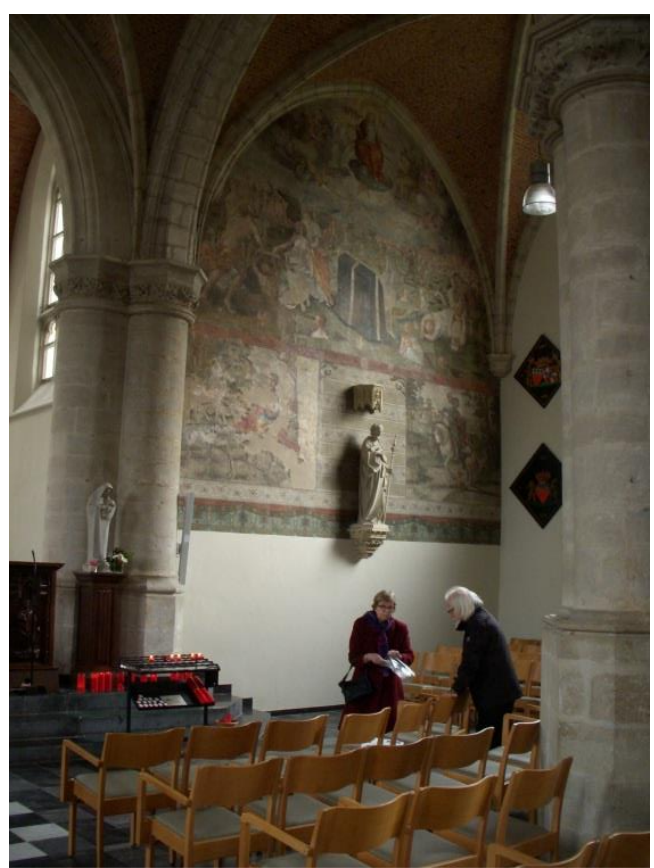

Fig. 15: Southern wall painting in transept (Above: The Final Judgment; Bottom left: St Hubertus; Bottom right: St Martin; $16^{\text {th }}$ Century) 
There was an imminent danger that the drilling and especially the drilling water might heavily damage the wall paintings. Therefore, the designing architect and the Church Fabric searched for alternatives to the original stabilizing concept in which more specifically the drilling operations behind the wall paintings could be skipped. The cracks in the dividing wall had been monitored with fissurometers over a period of about 10 years, Fig. 14. These fissurometers indicated that during that decade no measurable change of crack opening took place. Therefrom, the need for stabilizing anchors in the dividing wall could be questioned even more [4].

Because of that it was decided to launch an extensive foundation investigation, to search for the depth of the foundations as well as for the coherence and cohesion of the foundation masonry. The results of these investigations were combined with the results of soil investigations by means of penetrometer tests, to find an appropriate approach and solution for the structural problems of the church building.

\subsection{Foundation investigation}

Three investigation pits were dug near the foundation of the south façade, and two pits next to the tower. The location of the five pits is shown in Fig. 16. The investigations were carried out in July 2011.

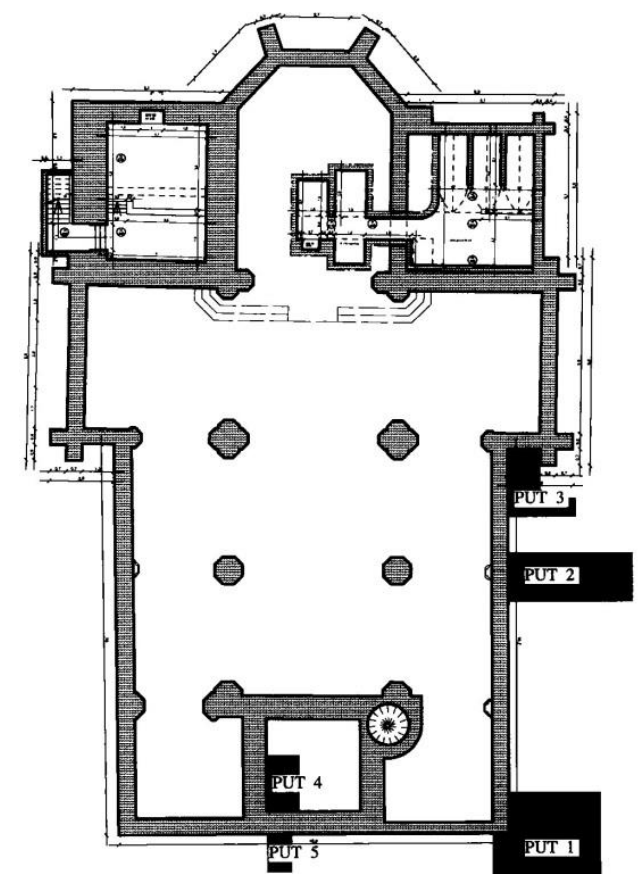

Fig. 16 Location of 5 investigation pits

In pit 1 at the SW-corner of the church building the reinforced concrete footing placed in the 1949-1950 restoration project was immediately found, Fig. 17. The footing projects $1.40 \mathrm{~m}$ to the south. The onset of the footing is at $1.30 \mathrm{~m}$ beneath ground level.

It was observed that the foundation masonry just above the footing was strongly eroded, as shown in Fig. 17. 


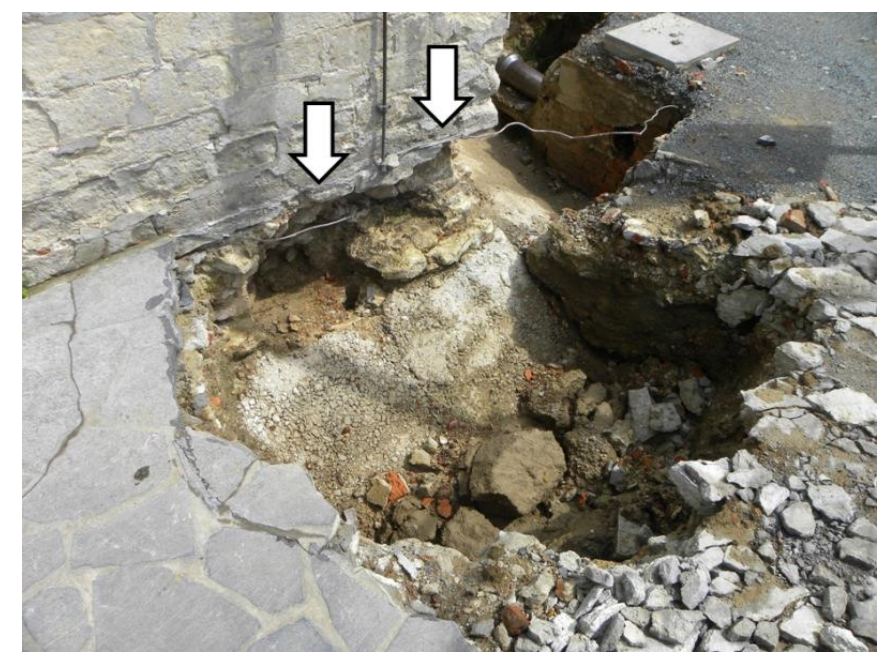

Fig. 17 Pit 1 Concrete footing. Erosion of masonry just above reinforced concrete footing, SW corner, pit 1 (zone under arrows)

In pit 2 at the south façade the same situation could be observed: very loose and eroded masonry above the concrete footing. The footing projects $1.15 \mathrm{~m}$ from the wall. Its onset is at $1.50 \mathrm{~m}$ below ground level.

Pit 3 next to the transept wall and the SW buttress of the transept is shown in Fig. 18. Here, the foundation masonry under the buttress is in good condition, with good cohesion. The onset of the transept foundation is at 1.9 à $2.0 \mathrm{~m}$ under ground level. The concrete footing projects $1.13 \mathrm{~m}$ out of the wall plane.

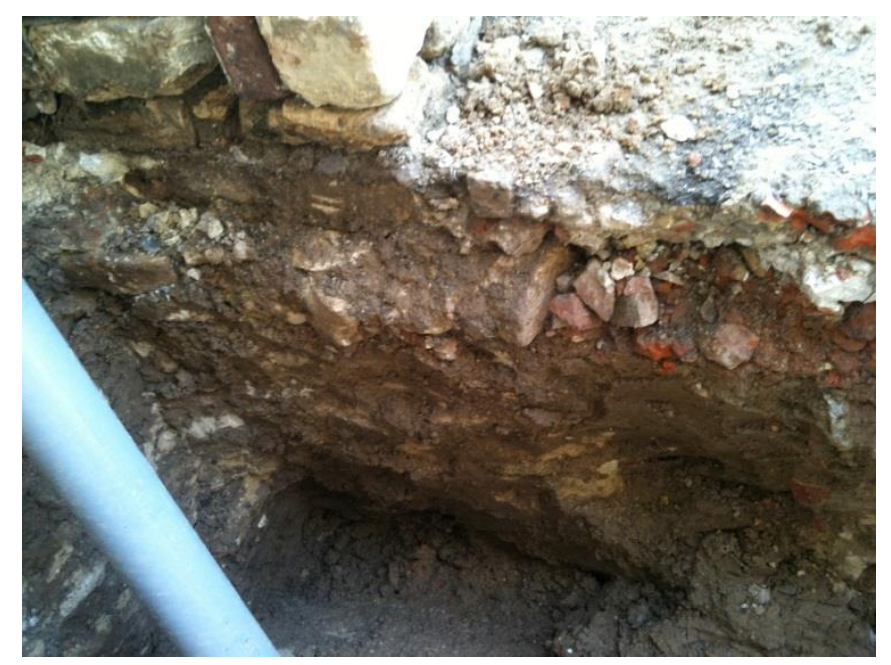

Fig. 18 Pit 3: foundation masonry of transept wall (left) and of SW buttress (right)

Pit 4 inside the tower is shown in Fig. 19. 


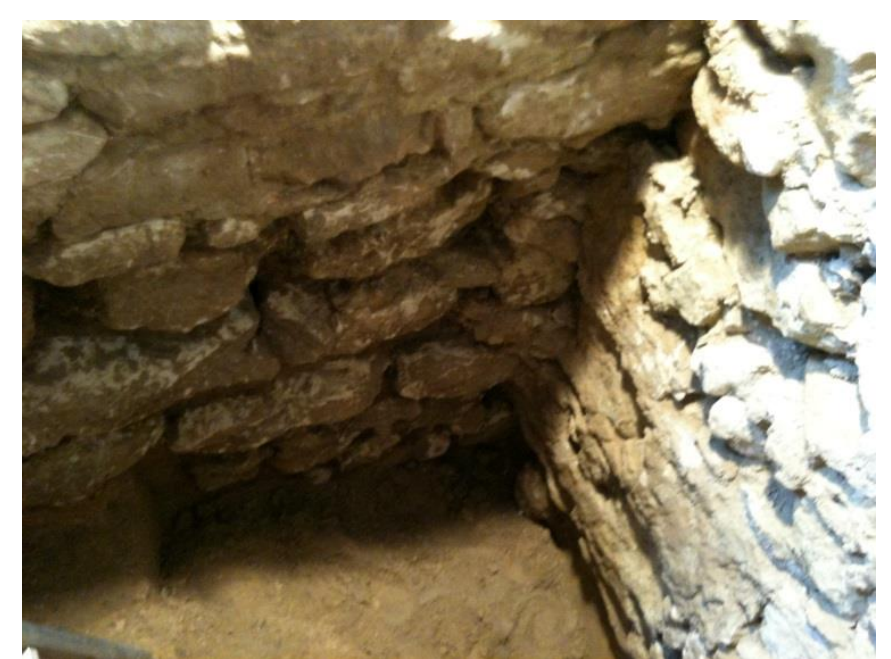

Fig. 19 Pit 4, inside of the tower foundation masonry, viewing direction NW

Fig. 19 clearly shows that in the bottom masonry the stone blocks are placed without laying mortar. Only the upper part is built with mortar. The onset is at $1.73 \mathrm{~m}$ under the pavement level in the tower. In pit 5 it could be observed that the front façade of the church projects about $20 \mathrm{~cm}$ out of the foundation masonry. However, with wall thicknesses of $1.1 \mathrm{~m}$ in the foundations, and $1.0 \mathrm{~m}$ in the tower shaft, such eccentricity hardly influences the vertical load and stress distribution.

Additionally, three cylindrical cores were taken in the foundation masonry, Fig. 20. Coring $\mathrm{B} 1$, length $1.50 \mathrm{~m}$, cored in the foundation of the $\mathrm{SW}$ buttress of the transept. coring B2, length $1.60 \mathrm{~m}$, cored in the foundation of the SW corner of the church. Coring B3, length $1.60 \mathrm{~m}$, cored in the foundation of the west wall of the tower at the junction with the south chapel.

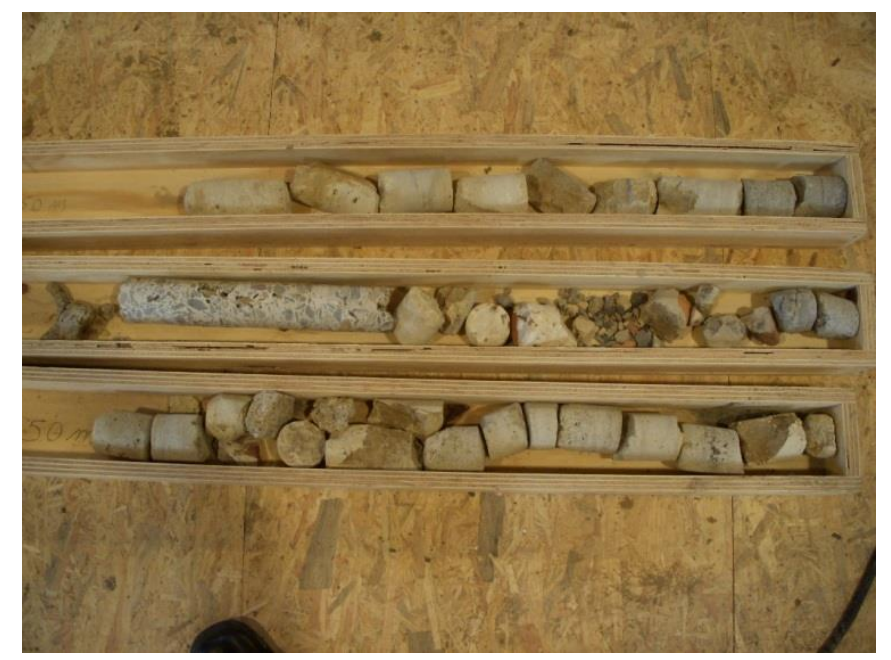

Fig. 20 Cored cylinders B1 (bottom), B2 (middle) and B3 (top)

The cored cylinders are presented in wooden boxes, with the start of the coring at the right side in Fig. 20. No joint mortar is found in the cores, because the coring with water cooled diamond coring crown dilutes and erodes the joint material, and as a consequence only natural stone fragments remain. At coring the drill master observed soil fragments, which confirms that the foundation masonry at the bottom is only a loose stack of blocks, without mortar. Core B2 at the SW-corner of the church contained a coherent piece of cement concrete. This anomaly in the foundation of an historic foundation was the direct reason for 
further research in the church archives, to find out the period and extent of eventual earlier restoration or strengthening works. As already mentioned above, that had been the case in 1949-1950.

The investigation pits and cored cylinders clearly showed that there was a problem with the cohesion and coherence of the foundation masonry. The extent of that problem was further investigated by means of endoscopic examination of the core of the masonry in different zones, see below.

The ground penetration tests also provided information on the soil composition: quaternary loam between 0 and $2.4 \mathrm{~m}$; between 2.4 and $7.4 \mathrm{~m}$ quaternary sandy loam to loam containing sand. Groundwater level was about $8 \mathrm{~m}$ under ground level[5].

The data of the ground penetration tests were used to calculate the expected settlements. The expected final settlements of the side walls of the church were calculated to evaluate the differential settlements of the church walls. For an estimated wall load of $170 \mathrm{kN} / \mathrm{m}$, and a footing width of $1 \mathrm{~m}$ (north wall), a total settlement of $35 \mathrm{~mm}$ has been calculated with the penetration data [5]. For a footing width of $3 \mathrm{~m}$ (south wall, concrete footing 1949) a settlement of $39 \mathrm{~mm}$ was calculated. This larger settlement result is due to the deeper influence zone of the acting soil tensions, when the foundation is wider. Of course this larger settlement goes together with much smaller soil pressures $\left(170 / 3=57 \mathrm{kN} / \mathrm{m}^{2}\right)$, ensuring less danger for soil failure.

Settlements started at the first building phases in the 18th century and have been growing with decreasing speed to the actual values. Part of the settlements and deformations have been built in during successive construction or transformation phases, like the incline of the south east crossing column, Fig. 10. The transept wall perfectly fits with the column, without any cracking in the wall plane. That is only possible when the wall is built afterwards against the inclined column. The same holds for the north-east column.

The baptistery chapel at north-west, as well as the storage chapel south-west, are detached from the tower at the building seems. The crack at both chapels is narrow at the bottom, and increasing to the top. As both chapels are additions later in time, that means that settlements of the tower at the moment of the chapel construction had already reached a nearly final stage. The chapel walls further away from the tower will settle more, whereas the parts against the tower do not settle anymore. The global movement of the chapel will thus become a tilting away from the tower, as observed. The tilting is smaller for the north chapel, and larger for the south chapel. However, in the north chapel an out of plane movement happened at the building seem with the tower, caused by the vault pressures from the brick masonry vaults in the chapel. Crack openings at the top are still limited to about $10 \mathrm{~mm}$, which means a differential settlement of about $5 \mathrm{~mm}$ between the corner of the chapels and the tower. The chapels are shown in Fig. 4 and Fig. 9.

The different movement for the north and the south chapels may be unexpected, but is explained by the additional uncovers in the investigation pits. At the north side the foundations have not been touched in the 1949 restoration project. However, at the south side the foundation footing has been enlarged, but the masonry has been disturbed and has been left behind in a certain 'pitiful' condition, see Fig. 17. The underpinning of the south wall was executed in about 15 strips, or phases, at which the wall was completely undermined to enable placing of a steel reinforcing cage and pouring of the concrete. It is certain that the larger settlement at the south wall is caused by the disturbance of the foundation masonry, because the disturbed masonry got more and more compacted and settled during the decades after 1949. 
Reading the settlements and deformations of the church building and comparison with calculated predictions learn that the settlements are finished for the major part, and that eventual additional settlements will remain very limited, and will not cause any structural instability or unsafe situation. Eventual small cracks that might still arise because of small settlements can easily be repaired at the next renovation round, presumably after 40 or 50 years, thus around 2050-2060.

\subsection{Consequences to the stabilization concept}

New foundation piles are not needed because the settlements nearly reached their final magnitude, except if additional loads would be applied at a specific place in the foundation. Pressures from the vaults in the chapels are met by means of local anchors. Continuous anchoring rods in the west façade may be skipped, because the chapels are not settling anymore.

Extra buttresses at the intermediate bays at the line of the free standing columns of the nave and at the line of the east wall of the tower will be constructed: two at the north wall and two at the south wall. The extra buttresses serve to strengthen the side walls, and are integrated in a new system to counteract the vault forces, see below. The buttresses are a local supplementary load on the foundation, and therefore they are placed on two micropiles each, in order to keep the actions on the existing foundations unchanged. A pile foundation can be applied next to the original direct foundation because the settlements are completed, and the settlement of the piles is negligible. No extra footing is constructed under the north side wall, because of completed settlements and safe foundation soil condition.

Where it is needed, the quality of the foundation masonry is improved by means of a consolidation injection with mineral grout. Masonry zones that have to be injected are searched by means of endoscopic investigation, see below.

An original system of tensile anchors is constructed to balance the vault forces in the nave and in the side aisles, in which no tension rods crossing the church interior are needed.

\subsection{Endoscopic search for voids and cracks in the masonry [6]}

The internal cohesion of the masonry is investigated by endoscopic inspection. Boreholes are drilled in the masonry ( $\varnothing 20 \mathrm{~mm}$, max. length $1.2 \mathrm{~m}$ ). The tubular optical instrument, connected to a digital camera or recorder, allows to inspect the side walls of the borehole. The presence of voids, cracks and joints can be detected in this way, allowing to evaluate the global cohesion and quality of the masonry, and to estimate the void ratio in the masonry. Downward boreholes in the north walls show the presence of natural stone over the top 50$60 \mathrm{~cm}$, and brick masonry at lower level. Stone masonry as well as brick masonry are well coherent, with nicely filled joints in between stones and in between bricks.

The foundation masonry of the NW baptistery chapel consists of natural stone masonry (upper $90 \mathrm{~cm}$ ), followed by brick masonry. Smaller holes were detected in the natural stone masonry (incomplete filling of joints). A larger void was detected at the transition from natural stone to brickwork, Fig. 21. 


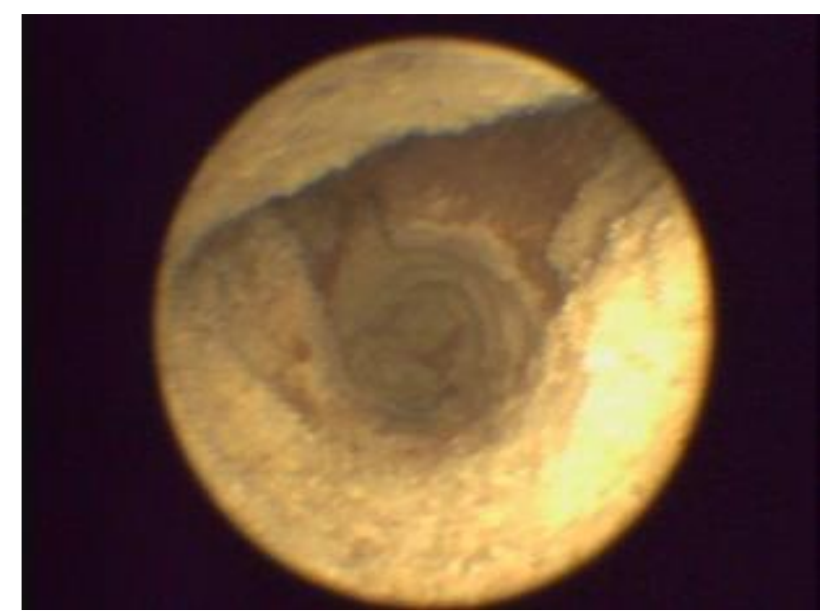

Fig. 21 Endoscopy E4, NW chapel, depth $85 \mathrm{~cm}$ : holes at transition of natural stone to brick masonry

Endoscopy E7 in the foundation of the SW buttress of the transept only showed natural stone masonry with very good coherence. Endoscopies in the south wall of the transept showed eroded parament, followed by brickwork masonry with good coherence. Endoscopies at different heights in the SW buttress of the transept all showed eroded parament masonry, followed by brickwork masonry with good coherence. The parament blocks in these zones were only stable because of the weight of the parament masonry above them.

\section{New structural concept}

\subsection{Consolidation injection of foundations}

To obtain a perfect, stiff and stable connection between the foundation masonry and the reinforced concrete footing under the south wall, the masonry was consolidated by means of an injection with mineral grout. The less coherent foundation masonry of the west wall of the baptistery chapel was injected as well. The used injection grout is a ternary lime-cementpozzolan grout. Its composition is as follows, per $100 \mathrm{~kg}$ binder powder:

- $\quad 20 \mathrm{~kg}$ hydrated lime (purity $\geq 92 \%$ )

- $\quad 40 \mathrm{~kg}$ slag cement CEM III/A 42,5 N LA

- $\quad 40 \mathrm{~kg}$ pozzolan (Rheinisch Trass)

- $\quad 85 \mathrm{~kg}$ (= 851 l) water (W/S = 0.85)

- $\quad 1 \mathrm{~kg}$ superplasticizer Glenium 27 or equivalent

At appropriate mixing [7] this grout has the following properties [8]:

- Compressive strength (28d) $\geq 5 \mathrm{MPa}$ (NBN EN 196-1)

- $\quad$ Bending tensile strength (28d) $\geq 1.5 \mathrm{MPa}$ (NBN EN 196-1)

- $\quad$ bleeding $\leq 4 \mathrm{vol} \%$

- flow test with Marsh cone $\leq 1$ min $20 \mathrm{sec}$ (immediately after mixing, using Marsh cone "OFI Testing Equipment, item 110-10" or equivalent, measured time = time for complete emptying of $1500 \mathrm{ml}$ fluid grout)

\subsection{Consolidation of detached parament masonry}

Eroded and detached parament masonry is searched by knocking with a hammer (acoustic auscultation), and detached zones are anchored in the core masonry with grout bond anchoring rods. Bonding is also done with the ternary mineral grout above, after repointing of 
the parament masonry. In such way the grout also serves to fill the voids between parament and core masonry, as well as to enhance the bond between parament and core.

\subsection{Structural measures}

Forces from the vaults above the nave are not balanced in the north-south direction. Therefore, a stabilizing construction is introduced in that direction. The north-south component of the horizontal vault forces is $35 \mathrm{kN}$ for the vaults above the central nave, and $15 \mathrm{kN}$ for the side aisles. Such force scan easily bend the freestanding walls like the exterior walls of the side aisles, but they can also easily be withstood by the parallel wall planes of the east and west transept walls with their buttresses. Because of historical settlements and by the action of vault forces, the nave and side aisles are bent open: in the nave the span between columns enlarged by $1.4 \mathrm{~cm}$ (between crossing columns) and even $4.7 \mathrm{~cm}$ (at choir, see also Fig. 10).

In the new concept the freestanding columns are shored up with an anchoring system, as schematically presented in Fig. 22.

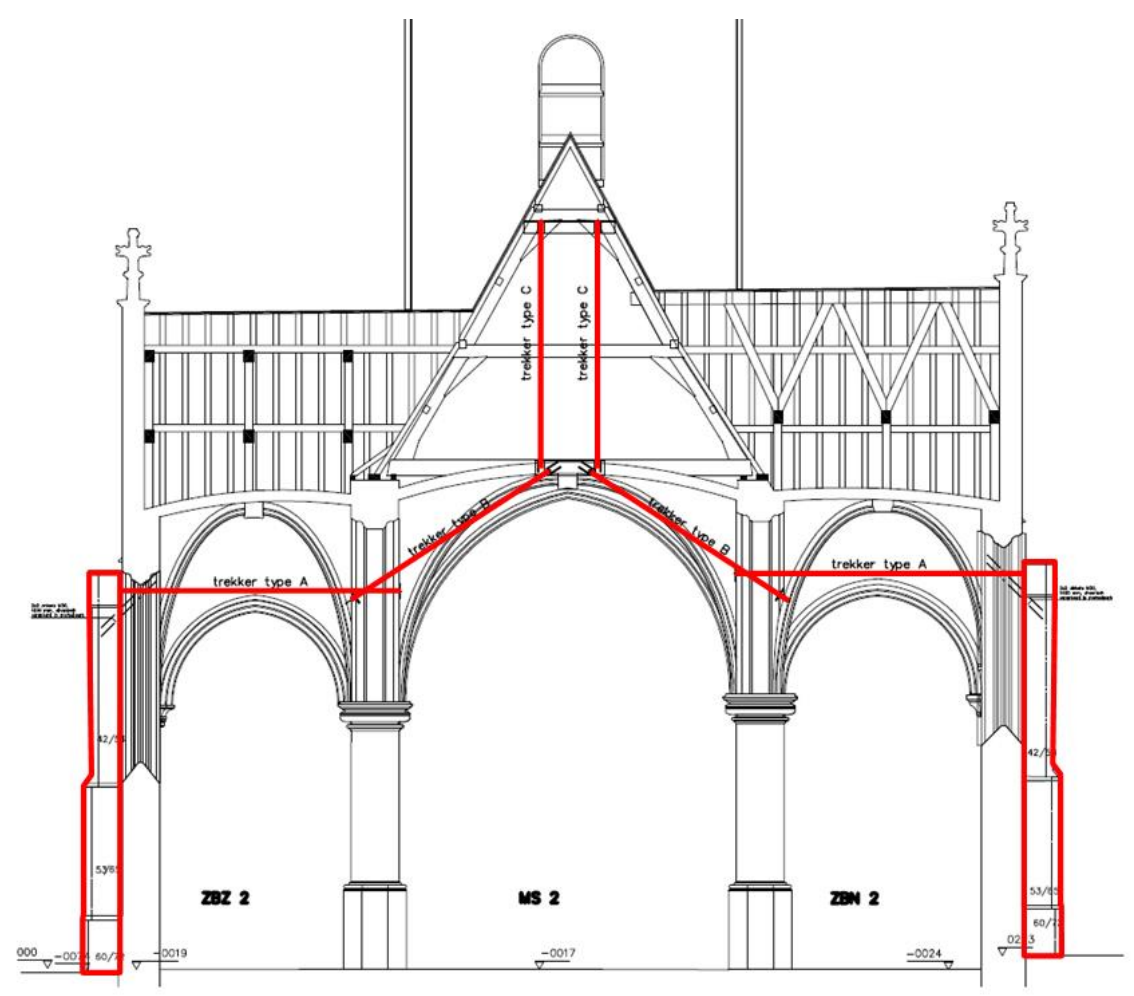

Fig. 22 Schematic layout of long anchors for freestanding columns. The inclined anchors above the nave vault are fixed to the tensile timber beam of the roof truss, which is on its turn supported by vertical anchors, fixed at the stiff triangular structure of the timber truss.

The anchors above the side aisle vaults are anchored in newly constructed buttresses. The vault forces from the side aisle vaults are acting horizontally on the buttresses, which are supported by the foundations at the bottom, and at the top they are supported by the anchors that connect them to the nave walls. In this way the newly constructed buttresses act as load carrying beams, able to withstand the vault forces, whatever the level may be at which these forces will act.

At the line of the east wall of the tower the anchors are placed as shown in Fig. 23. 


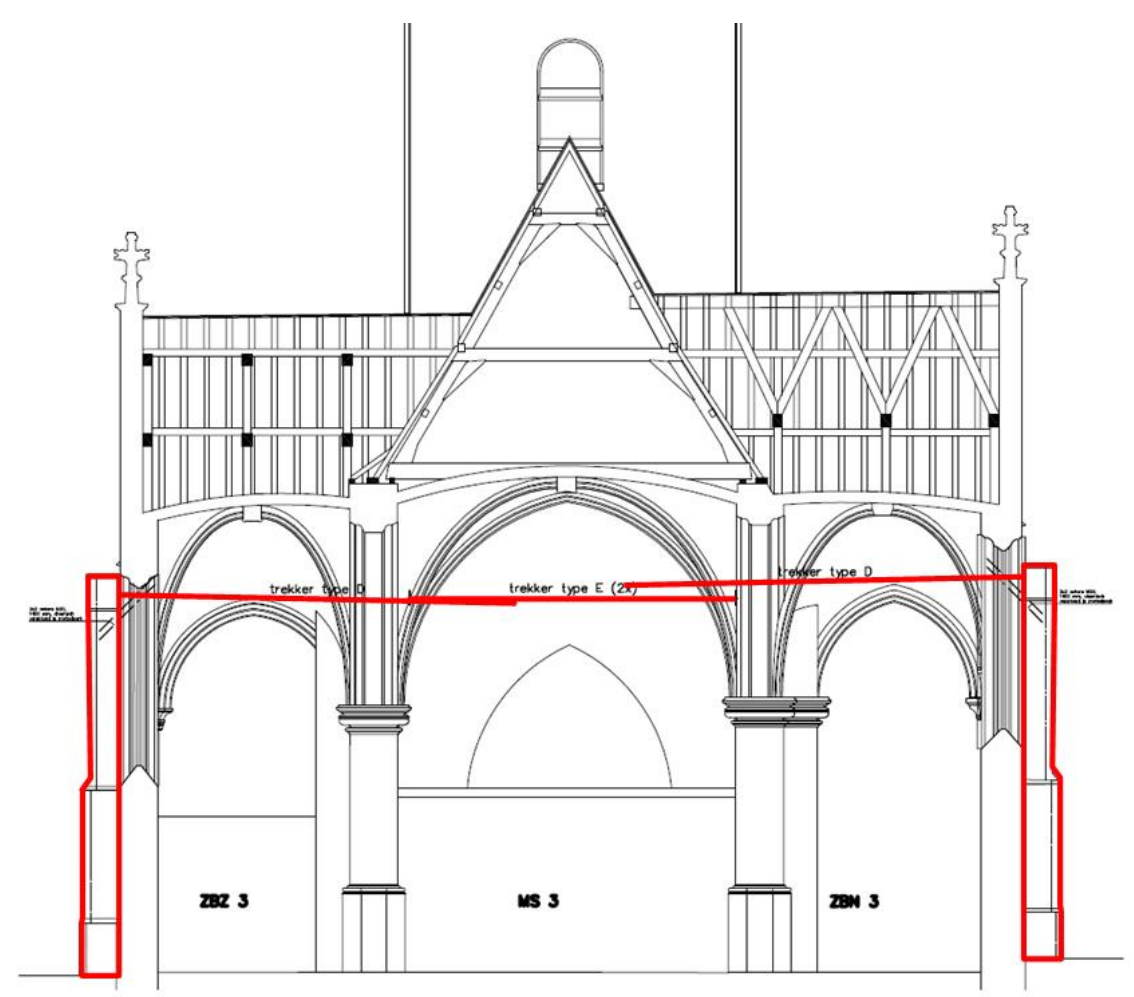

Fig. 23 Schematic layout of anchors at east wall of the tower. Tensile rods are anchored in the massive tower masonry.

The left tensile rod is drilled in the main arch above the rood loft of the south storage chapel, and further on in the tower shaft. Reading of the cracks and deformations learned that future settlements will remain very limited, and therefore no additional long anchors are placed in the wall between choir and transept (see Fig. 14). However, cracks in the north façade of the transept, in the west wall of the tower, as well as the building seems between chapels and tower are 'stitched' with short anchors.

\section{Execution}

\subsection{Consolidation injection of masonry}

The foundation masonry of the south wall, and the foundation masonry of the west wall of the north chapel are instrumented with injection tubes, and injected with ternary grout. The consumption of ternary grout was about 3800 liter for a total injected volume of $20 \mathrm{~m}^{3}$ of masonry. This means a consumption of about 18 to $20 \mathrm{vol} \%$ of the foundation masonry.

For the injection of façade wall masonry and for the anchoring of the paraments, a total volume of 1800 liter of grout was used. This would mean a consumption rate of only 1 à 2 vol \%, but one must bear in mind that the grout is concentrated in anchor holes and in the paraments.

\subsection{Extra new buttresses at north and south walls}

The locations of the two new buttresses at the north wall and of the two new buttresses at the south wall are given in Fig. 26. Each buttress is built on a foundation footing, supported by two micropiles in order to keep the loads on the existing foundation unchanged. The footing is anchored in the existing foundation masonry by means of drilled and glued anchors, to 
compensate for the eccentricity of the piles under the footing. The micropiles have a length of $12 \mathrm{~m}$, and an effective diameter of $140 \mathrm{~mm}$. The pile reinforcement is a self-drilling hollow rod with external diameter of $38 \mathrm{~mm}$, and with a drilling head of $76 \mathrm{~mm}$ diameter. The pile reinforcement is anchored in the footing of the buttress.

The core of the buttress is made in reinforced concrete, and is connected to the walls with grouted steel anchors, Fig. 24.

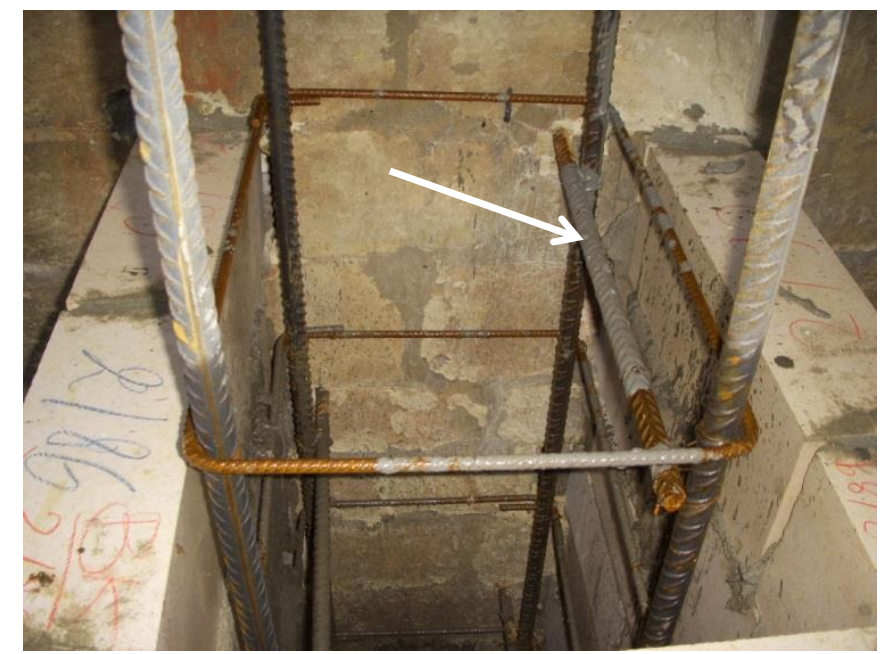

Fig. 24 Anchoring of concrete core of buttress with grouted anchors (arrow)

The buttresses are built in successive parts, Fig. 23. They are composed of a natural stone parament around a reinforced concrete core. Care is taken to obtain a perfect connection between parament and core, to avoid large holes where water accumulation through condensation could happen, leading to frost damage.

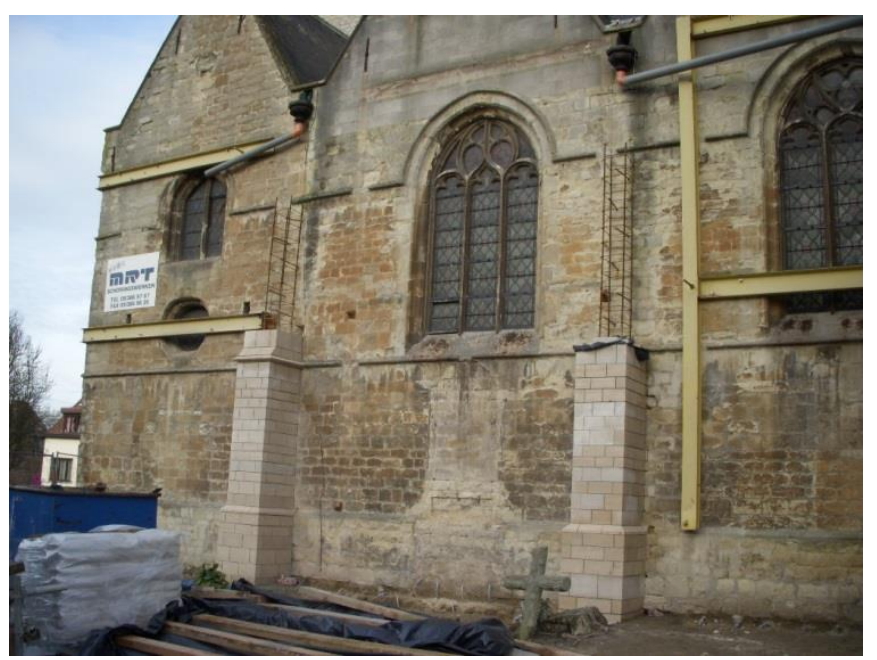

Fig. 25 Construction of buttresses in successive vertical parts

The tensile rods above the side aisle vaults are anchored in the top of the buttress, Fig. 22 and 23. Then the head of the buttress can be finished, Fig. 26. 


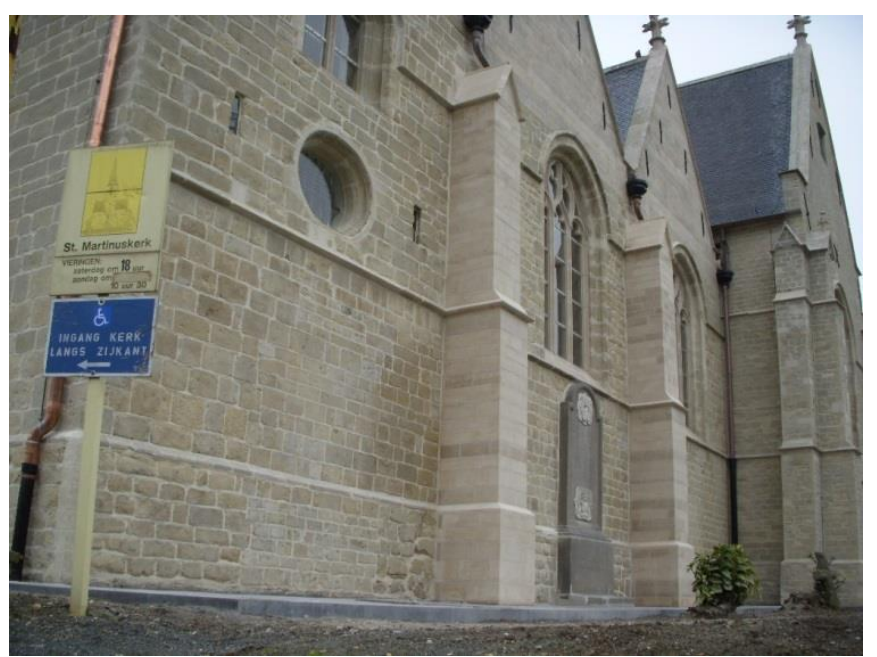

Fig. 26 Finished buttresses at south wall

\subsection{Long anchors}

The long anchors are stainless steel rods. A tensile rod system is placed in the line of the freestanding columns of the nave, according to the principle shown in Fig. 22. The anchors in the line of the east wall of the tower, as schematically shown in Fig. 23, are completed with an overlapping tensile rod in the interior of the tower to obtain a continuous connection from north to south. Horizontal anchors are also placed at a height of $6.6 \mathrm{~m}$, also in the interior of the tower, to take up the splitting forces generated by the large openings in the east wall of the tower (rood loft) and in the west wall of the tower (window).

The forces from the vaults above the side aisles are taken up by the new buttress and by the nave wall, where the tensile rod type A (Fig. 22) locks the buttress and the nave wall. The forces from the nave vaults are taken up by the inclined rods type $\mathrm{B}$, connected to the main beam of the roof truss. The vertical component of the force in the tensile rod is compensated by the weight of the wall part above the crossing between anchors A and B. To avoid deflection of the main beam, it is hung up with two vertical tensile rods type $\mathrm{C}$ to the triangular structure of the roof truss. Fig. 22 also shows schematically the connection of the tensile rods type A in the top of the buttress. Figures 27 to 29 show the practical execution of this innovative tensile anchor system.

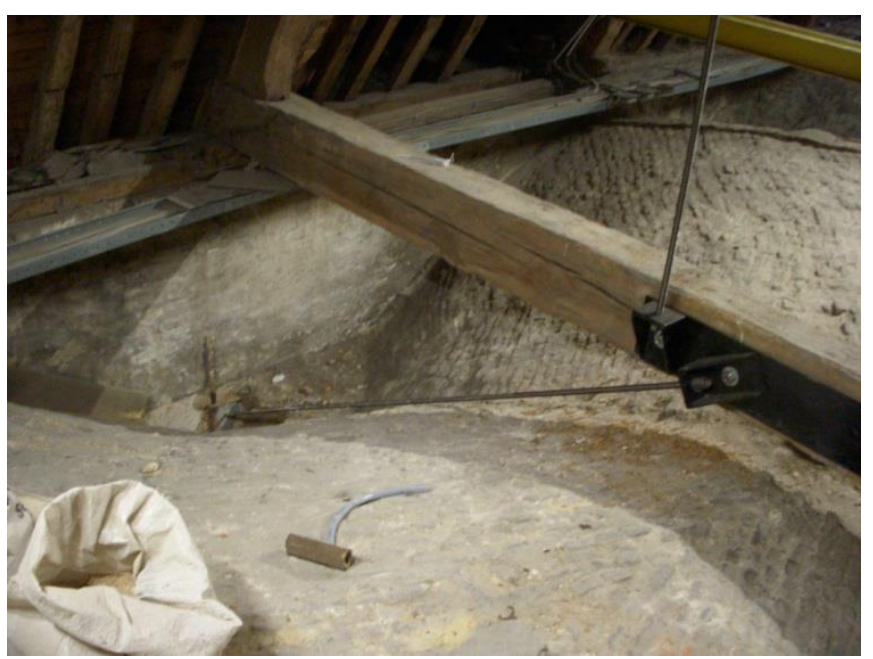

Fig. 27 Inclined anchor type B 


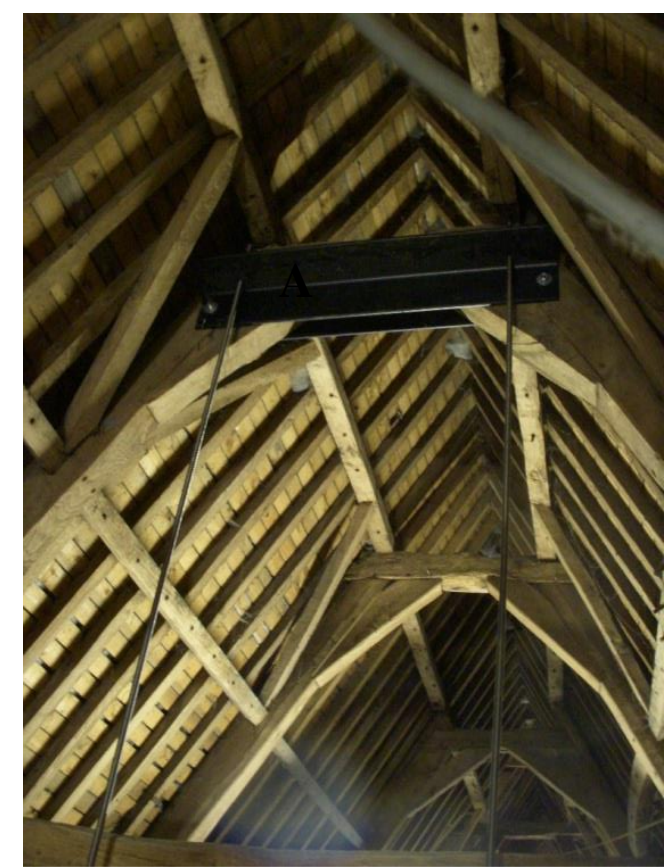

Fig. 28 Suspension of main beam with anchors type C

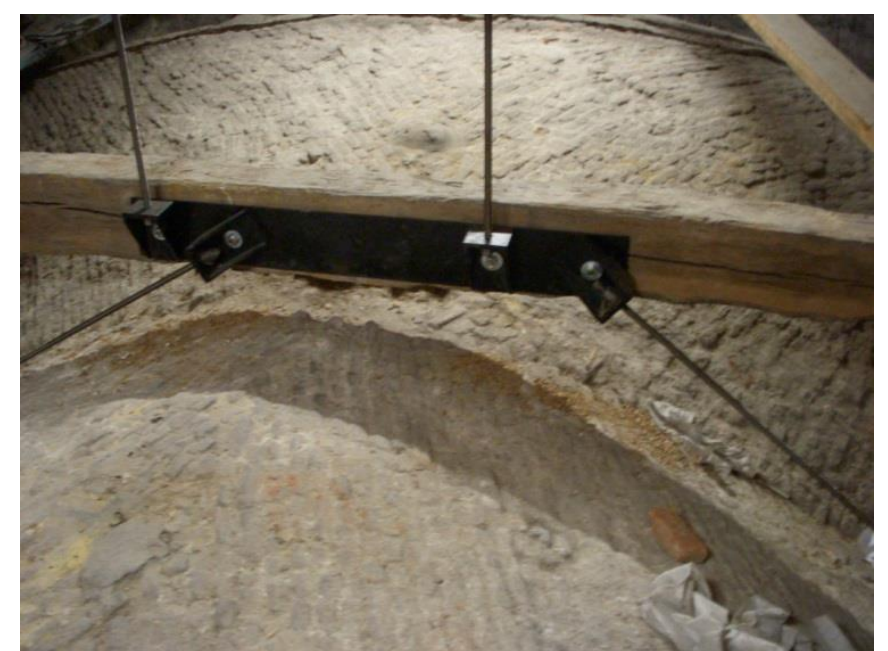

Fig. 29 Connection of anchors type B with main timber beam of roof truss

This layout of the anchoring system avoids anchors in the church interior. It delivers an open and attractive church space to the community.

\subsection{Stitching of cracks}

The crack in the west wall of the tower is strengthened with bored in, grouted anchors according to the scheme in Fig. 30. The cracked and shifted building seems between the tower and both chapels are strengthened or 'stitched' in the same way. 


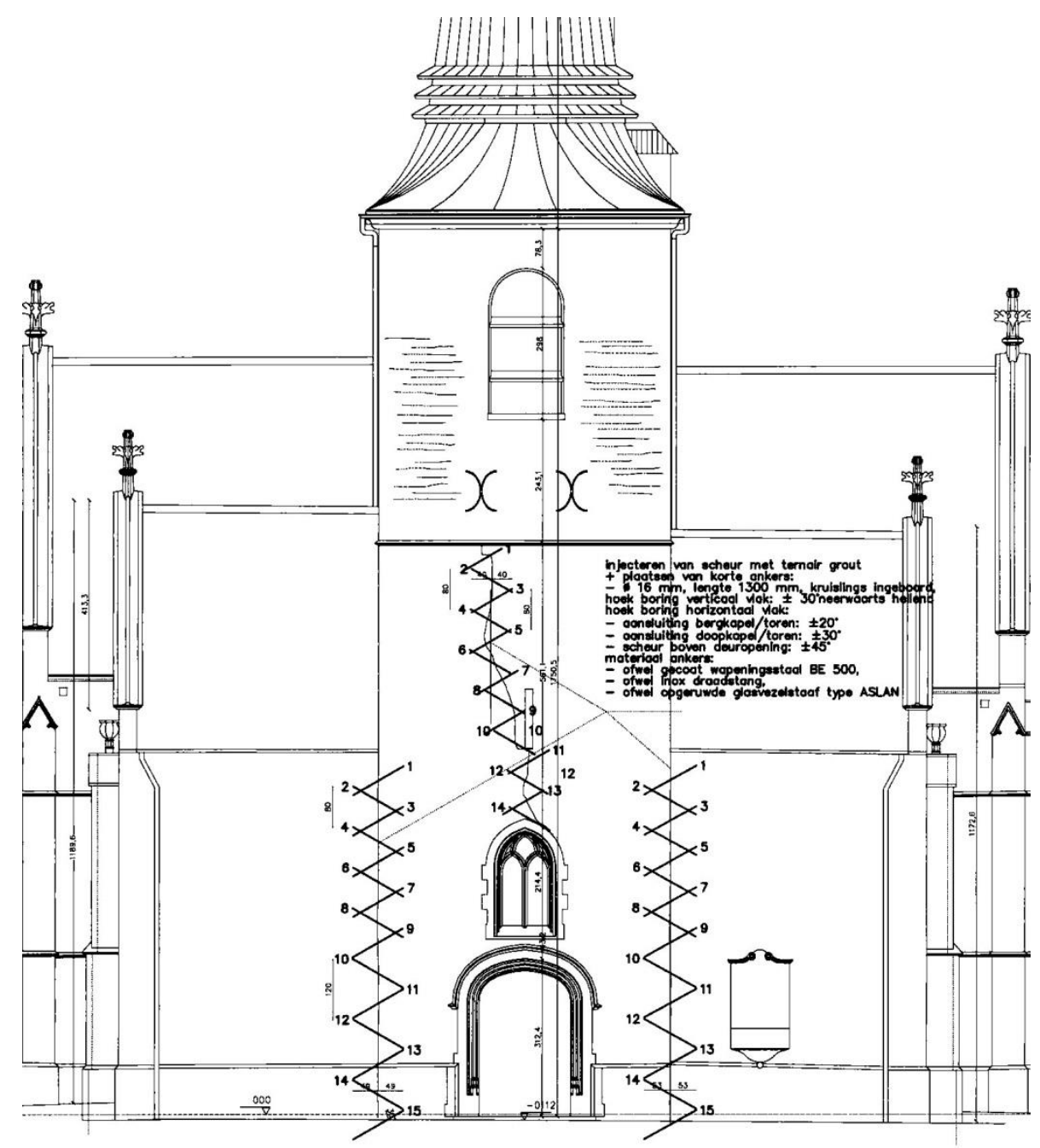

Fig. 30 Stitching of cracks and seems in the west façade

\section{Particular aspects}

\subsection{Consolidation of vault tips}

After cleaning of the vaults, the size and type of the vault deformations became clearly visible. The suspicious deformations are twofold:

- local bulging

- detached vault ribs.

Some bulged vault parts were examined by means of endoscopic investigation. Endoscopies were executed in the south aisle, vault part adjacent to the transept wall, in the north aisle, also in the vault part adjacent to the transept wall. The endoscopic examination is the visual inspection of the walls of a borehole with diameter $16 \mathrm{~mm}$, Fig. 31 [9]. 


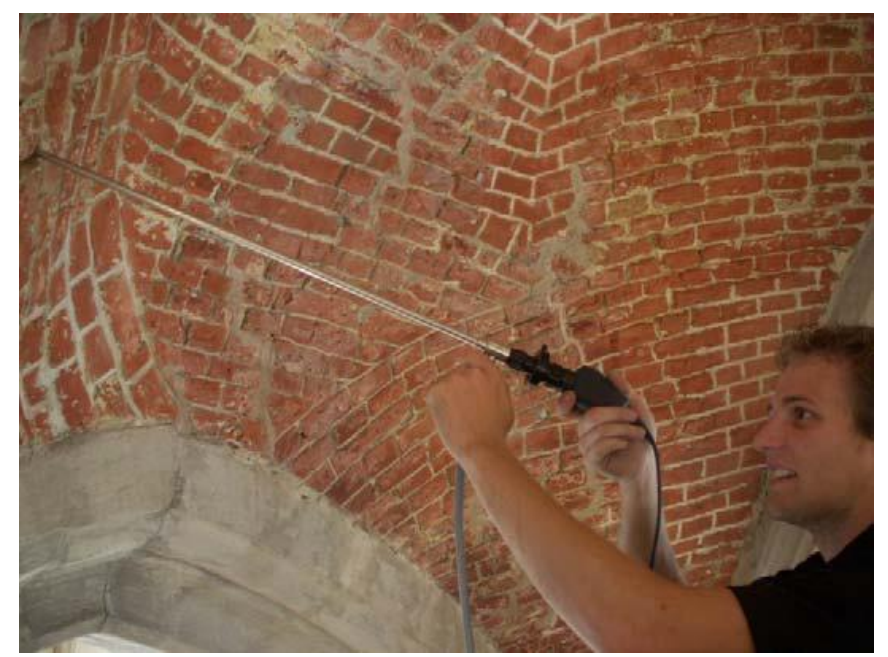

Fig. 31 Endoscopic examination

It was found that the vault thickness in the bulged zones was only 7 to $10 \mathrm{~cm}$. In these lower parts the vault thickness is only half-brick, whereas it is full brick in the upper zones. At boring the hole, a dark and crumbly powder flows out of the hole. The borehole walls are very porous and incoherent. They consist of a light colored lime mortar and fragments of brick, stone and slate. The inside of the vault in the bulged zone is plastered at several places (thickness 2 to $3 \mathrm{~cm}$ ), with painted brick pattern.

The brickwork of the vault in the bulged zones is heavily cracked and very soft. Combined with the loose backfill at the vault tips, this creates a dangerous and unstable situation, ultimately leading to brick fall. For that reason the bulges are consolidated with sock anchors, provided with a wider pinion at the vault inside to support the masonry. Sock anchors have a diameter of 10 to $12 \mathrm{~mm}$, with at the center a reinforcing element with diameter 6 to $8 \mathrm{~mm}$. Sock anchors can be placed in a borehole of 12 to $14 \mathrm{~mm}$. Pinion and sock anchor are glued in the borehole with a mineral grout. The borehole at the inside of the vault is widened to allow a hidden placement of anchor and pinion.

In this case copper tubes have been used as reinforcing element, Fig. 32 and 33. The tube is put in a textile sock. The tube is used to inject the mineral grout in the sock. The sock is pressed against the borehole wall by the injected grout. The small amount of grout that penetrates through the sock assures the bond of the anchor in the borehole.

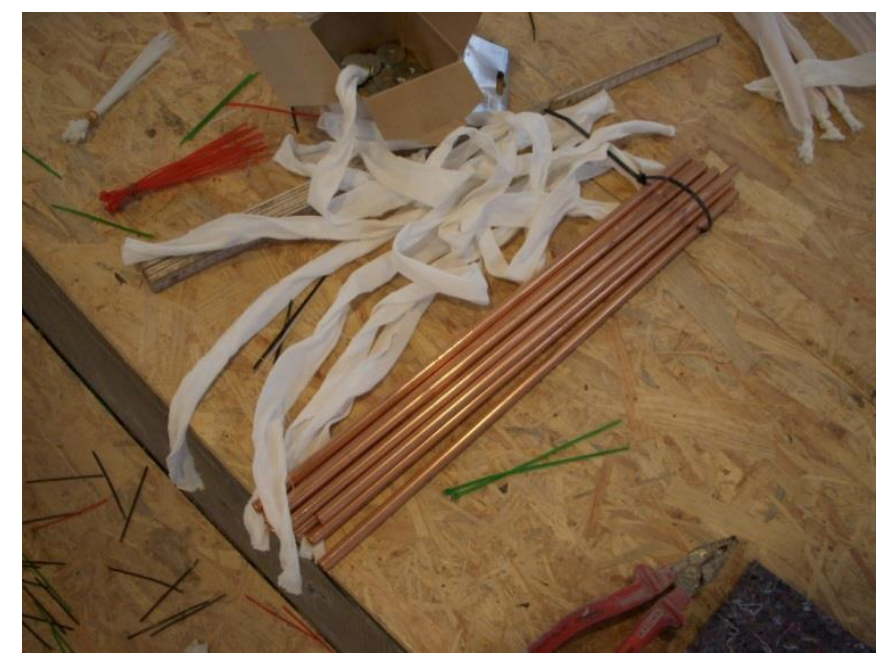

Fig. 32 Sock anchors: copper injection and reinforcing tube 


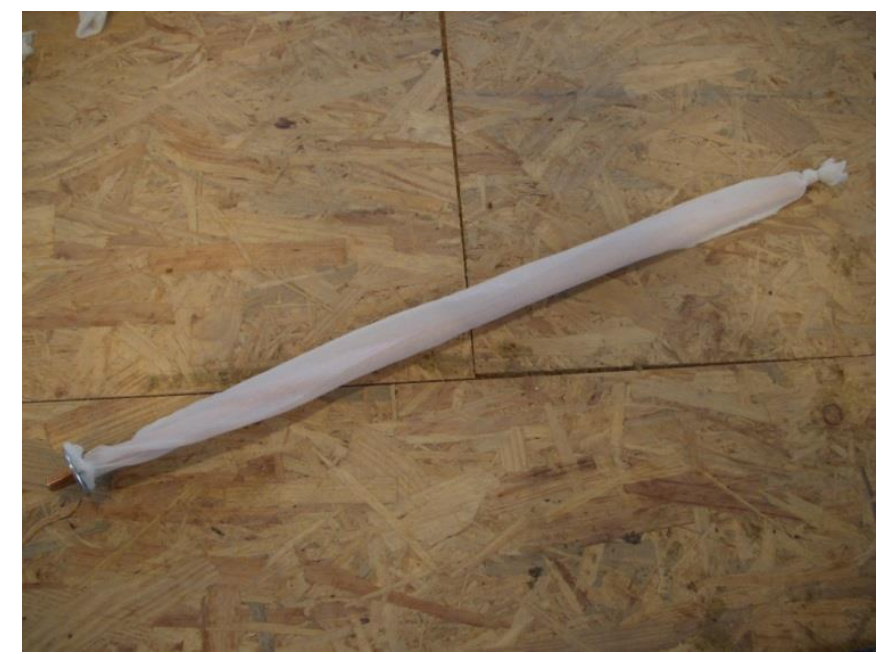

Fig. 33 Completed sock anchor, with pinion at the left end

Five suspicious vault zones have been consolidated and strengthened with this type of sock anchors.

\subsection{Detached vault ribs}

A detached rib was discovered in the choir after cleaning of the vaults. The detached rib is shown in Fig. 34.

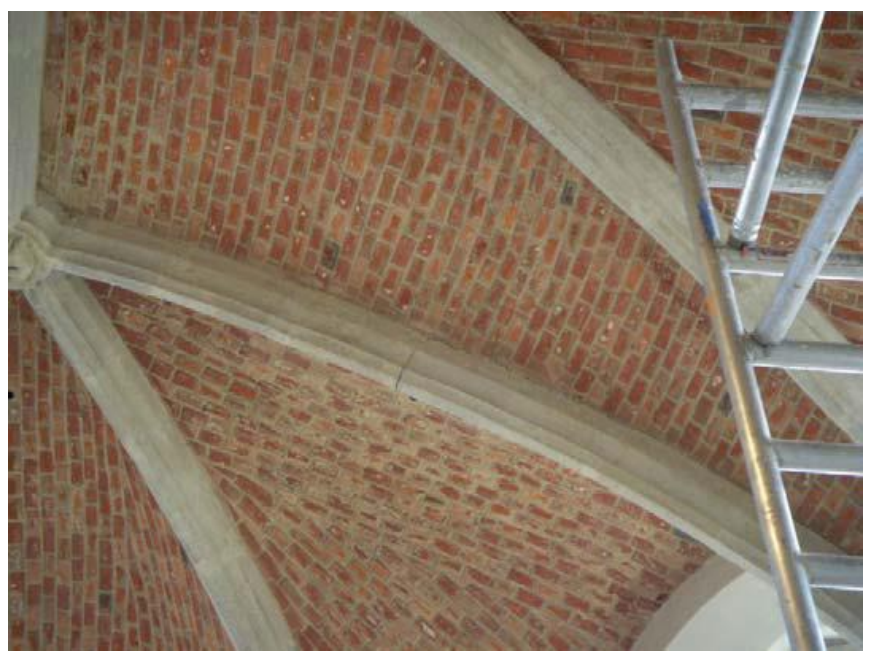

Fig. 34 Detached vault rib

The detached ribs is joined with the masonry vault by means of sock anchors, Fig. 35 . The sock anchors are bored in and grouted from above. In this way the rib forms a unity with the vault masonry, and the composite structure acts as vault supporting rib. 


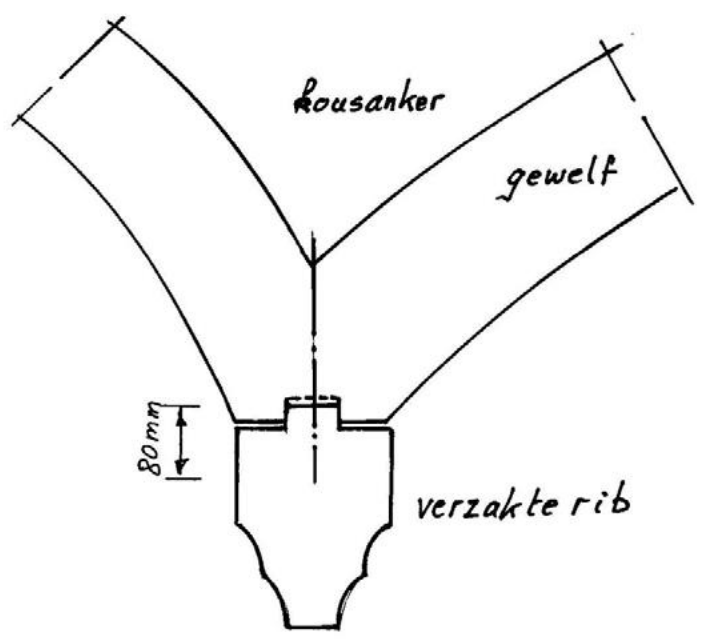

Fig. 35 Scheme of joining a detached rib to the masonry vault by means of sock anchors. Sock anchor length is $25 \mathrm{~cm}$.

The use of sock anchors avoids the grout to flow out of the borehole through the fissure between rib and vault. Here again the ternary mineral grout was used as adhesive.

\subsection{Consolidation of buttresses and gables of side aisles (wimpergs)}

\subsubsection{Buttresses}

The stone masonry at the top of the transept buttresses is strongly eroded, Fig. 36. By ingress of rain water and by frost-thaw effects the coherence is disturbed: the parament blocks are lying on each other without mortar bond. Therefrom, demounting the parament stones was very simple, Fig. 37. A lot of plant roots were present at the transition between parament and core masonry.

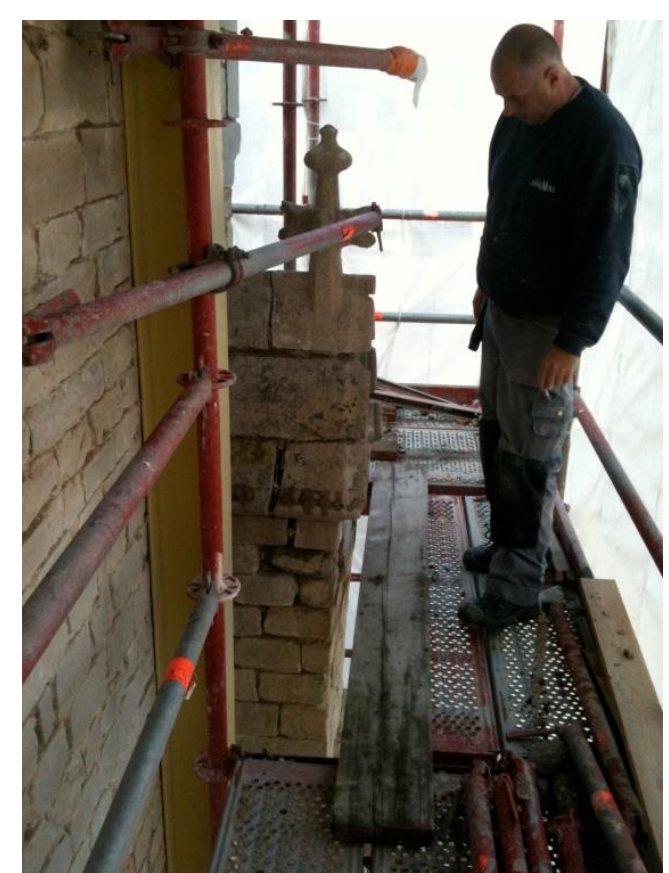

Fig. 36 Degraded masonry at top of transept buttress 


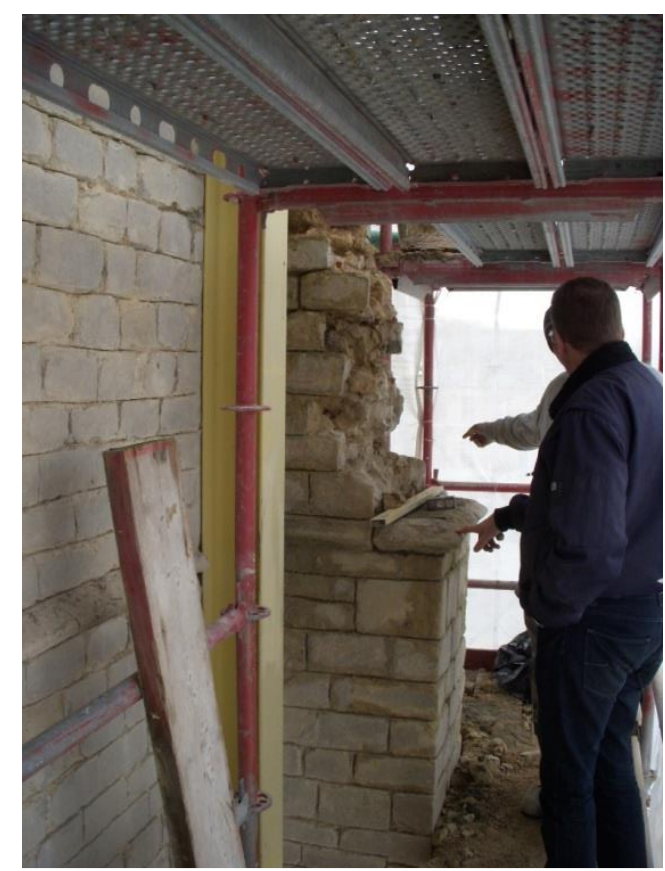

Fig. 37 Demounting of the top part of a transept buttress

The degraded core masonry is removed till no vegetation roots could be found. After that, stainless steel anchoring rods ( $\varnothing 16 \mathrm{~mm}$, length $600 \mathrm{~mm}$ ) were bored in every $25 \mathrm{~cm}$, and grouted with ternary grout. The anchoring depth in the core masonry is $300 \mathrm{~mm}$, whereas the remaining $300 \mathrm{~mm}$ is embedded in the new, substituting core masonry composed of massive bricks, placed with a lime-cement mortar: 1 volume part of hydrated lime, 1 part of cement, 5 parts of sand (in weight parts: $6 \mathrm{~kg}$ hydrated lime, $10 \mathrm{~kg}$ cement, $80 \mathrm{~kg}$ sand). After replacing a row of parament stones, the vertical joint between the core and the parament is filled with ternary grout, to ensure a perfect contact and bond between both. The original parament blocks could be reused for the reconstruction of the transept buttresses.

\subsubsection{Restauration of the paraments of the wimpergs}

The parament masonry of the northern wimpergs is strongly degraded, Fig. 38. The southern wimpergs are in better condition, because they already have been renovated at an earlier restoration phase around 1900, in which these southern wimpergs were renewed with Euville natural stone. 


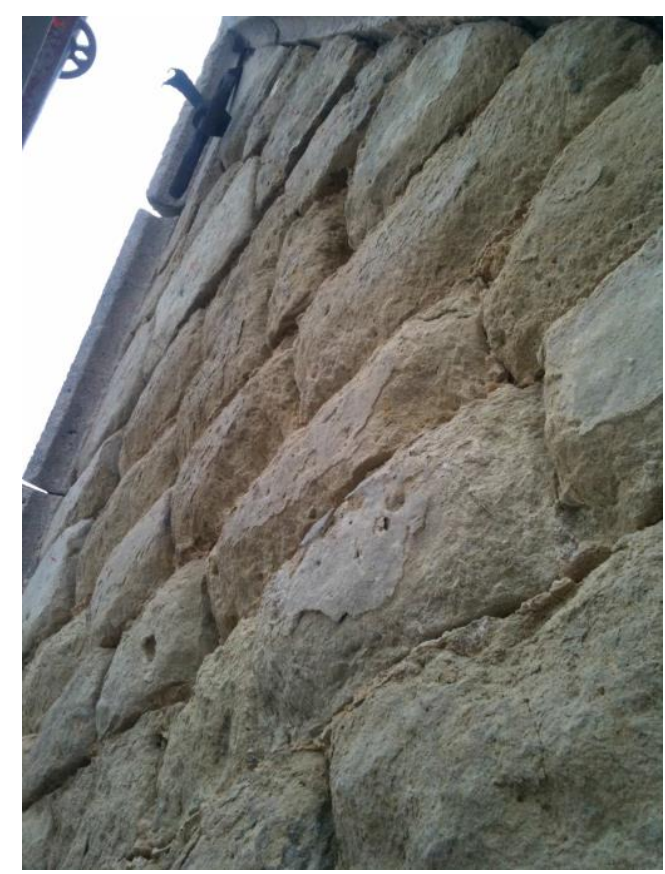

Fig. 38 Strong exfoliation of Ledian natural stone at the northern wimpergs

Because of this strong degradation it was decided to demount the three northern wimpergs piece by piece and stone by stone, and to replace them in the same configuration. Heavily degraded blocks were recut when possible. Missing blocks were replaced by new stones of Massangis roche jaune. The replaced parament is anchored in the backing masonry by means of grouted anchors. For each row of parament stones, anchors are grouted with ternary grout in the masonry behind, and the vertical joint was first filled with mortar as good as possible. After that the vertical joint was further filled with ternary grout to obtain a complete filling of all voids between mortar and masonry, as well as to obtain a partial consolidation of the backing masonry. This procedure is repeated at each row of replaced parament stones. The consistency of the grout allows its use for about two hours. Therefore, grouting did not hinder at all the block laying activity. The execution is shown in Figures 39 and 40.

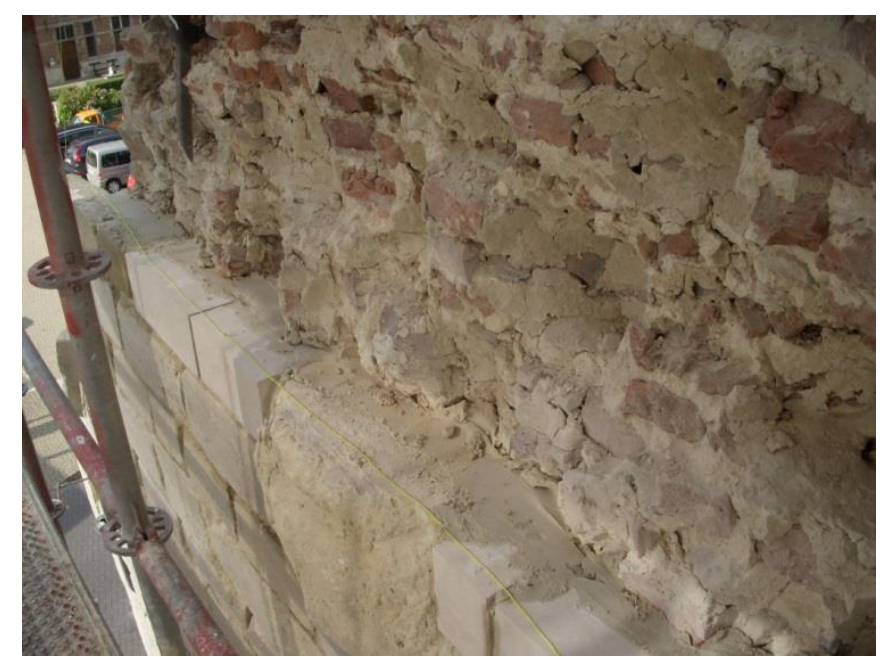

Fig. 39 Row per row reconstruction of a wimperg, with complete filling of the vertical joint between parament and backing brick masonry 


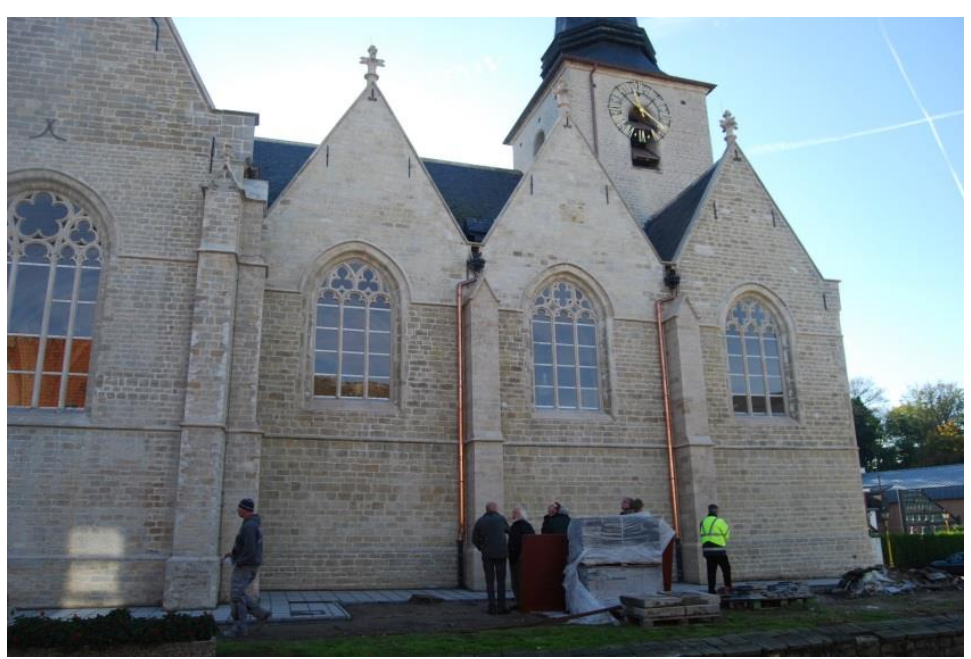

Fig. 40 Renewed wimpergs at north side (Photograph D. Snauwaert)

\section{Conclusions}

The integrated approach of the restoration of St Martin church at Meise resulted in an open and attractive building for the community, without disturbing tensile anchors or supporting frames in the interior, Fig. 41.

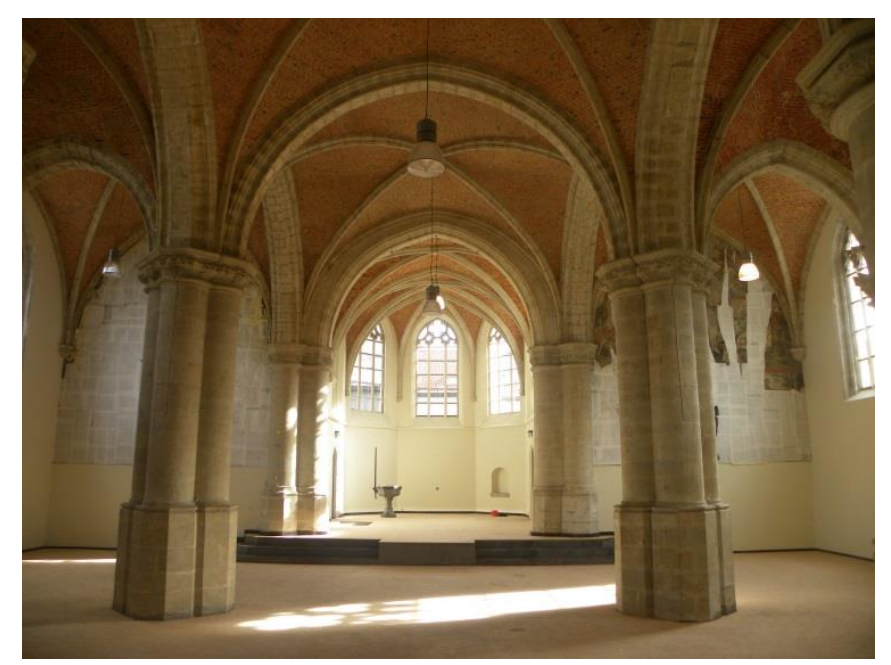

Fig. 41 Interior of St Martin church after restoration

The interaction between building and foundation was taken into account at designing the necessary consolidation measures, at which the study of the archives had an important role. The archive search learned that important strengthening works had been executed in the period 1949-1950, which shed a new light on the observed deformations and crack patterns in the church. It enabled to strictly limit the interventions at the foundations: the crack pattern could be linked to settlements due to compaction of foundation masonry disturbed by these earlier interventions.

Through manipulation of the force distribution between vaults and supporting columns and walls and by adding four new buttresses, a simple tensile anchor system could be installed that completely remained in the attics above the vaults for the bays with freestanding columns, and completely embedded in the walls for the bay at the tower. 
The safety of the wimperg paraments was obtained by means of a combined use of traditional building techniques with anchoring and consolidation technologies based on the use of ternary lime-pozzolan-cement grout.

\section{Acknowledgements}

Building owner at the restoration of St Martin church at Meise was the Municipality of Meise. Designing architect was Dirk Geeroms. Triconsult nv was consulting engineering office. Monument Vandekerckhove nv was contractor. Heritage Flanders was represented by Inge Debacker and Els Patrouille. The church fabric was represented by Reverend Father Jan Lagae, sister Dominica, Wilfried Van Campenhout, Jaak Santermans and Paul Van de Velde. Special thanks go to alderman Dirk Snauwaert, who phlegmatically supported and followed the restoration project. The authors express their special thanks to Jaak Santermans and Paul Van de Velde, for their successful searching in the archives.

\section{References}

1. De Maegd C., Van Aerschot S., Inventaris van het cultuurbezit in België, HalleVilvoorde, Bouwen door de eeuwen heen in Vlaanderen 2N, Gent, 1975

2. Degand Victor, Procès-verbal d'expertise - Église paroissiale de Meysse à l'effet d'examiner la solidité par suite des fissurations, 8th August 1939

3. Degand Victor, Restauratie van de parochiale St.-Martinuskerk, Beschrijvend Bestek, Brussel, 10 december 1948

4. Heirman G., Van Gemert D., Meise Sint-Martinuskerk. Nota conceptuele begeleiding standzekerheidsaspecten, Triconsult D00876-11, 08 augustus 2011 (internal report)

5. Geologica nv, Grondonderzoek te Meise, Sint-Martinuskerk, D21494, 16.02.1999

6. Heirman G., Van Gemert D., Meise, Sint-Martinuskerk. Nota endoscopisch onderzoek, Triconsult D00876-11, 6 oktober 2011 (internal report)

7. Toumbakari E.-E., Van Gemert D., Lime-pozzolana-cement injection grouts for the repair and strengthening of three-leaf masonry structures, Proceedings 4th International Symposium on the Conservation of Monuments in the Mediterranean, Rhodos 6-11 May 1997, Vol. 3, pp. 385-394

8. Van Gemert D., Ignoul S., Brosens K., Toumbakari E.-E., Consolidation and strengthening of historical masonry by means of mineral grouts: grout development Restoration of Buildings and Monuments, Vol. 21, 2015, 29-45 Doi 10.1515/rbm-2015-0004

9. Verreydt K., Van Gemert D., Sint-Martinuskerk Meise. Nota beveiliging gewelven. Triconsult D00876-11, 10 september 2012 (internal report) 